\title{
A global compilation of dissolved iron measurements: focus on distributions and processes in the Southern Ocean
}

\author{
A. Tagliabue ${ }^{1,2, * *}$, T. Mtshali ${ }^{1,3, * *}$, O. Aumont ${ }^{4}$, A. R. Bowie ${ }^{5}$, M. B. Klunder ${ }^{6, *}$, A. N. Roychoudhury ${ }^{3}$, and S. Swart ${ }^{1,2}$ \\ ${ }^{1}$ Southern Ocean Carbon and Climate Observatory, CSIR, P.O. Box 320, Stellenbosch, 7599, South Africa \\ ${ }^{2}$ Department of Oceanography, University of Cape Town, Cape Town, 7701, South Africa \\ ${ }^{3}$ Department of Earth Sciences, Stellenbosch University, Stellenbosch, 7602, South Africa \\ ${ }^{4}$ Laboratoire de Physique des Océans, Centre IRD de Bretagne, 29280 Plouzané, France \\ ${ }^{5}$ Antarctic Climate and Ecosystems Cooperative Research Centre (ACE CRC), University of Tasmania, Private Bag 80, \\ Hobart, TAS 7001, Australia \\ ${ }^{6}$ NIOZ, Dutch Institute for Sea Research, Den Burg, Texel, The Netherlands \\ *now at: Centre for Assessment of Pesticides and Biocides, Wageningen, The Netherlands \\ ***These authors contributed equally to this work.
}

Correspondence to: A. Tagliabue (atagliab@gmail.com), T. Mtshali (tmtshali@csir.co.za)

Received: 1 November 2011 - Published in Biogeosciences Discuss.: 30 November 2011

Revised: 16 April 2012 - Accepted: 11 May 2012 - Published: 29 June 2012

\begin{abstract}
Due to its importance as a limiting nutrient for phytoplankton growth in large regions of the world's oceans, ocean water column observations of concentration of the trace-metal iron $(\mathrm{Fe})$ have increased markedly over recent decades. Here we compile $>13000$ global measurements of dissolved $\mathrm{Fe}(\mathrm{dFe})$ and make this available to the community. We then conduct a synthesis study focussed on the Southern Ocean, where dFe plays a fundamental role in governing the carbon cycle, using four regions, six basins and five depth intervals as a framework. Our analysis highlights depth-dependent trends in the properties of dFe between different regions and basins. In general, surface $\mathrm{dFe}$ is highest in the Atlantic basin and the Antarctic region. While attributing drivers to these patterns is uncertain, inter-basin patterns in surface $\mathrm{dFe}$ might be linked to differing degrees of $\mathrm{dFe}$ inputs, while variability in biological consumption between regions covaries with the associated surface dFe differences. Opposite to the surface, dFe concentrations at depth are typically higher in the Indian basin and the Subantarctic region. The inter-region trends can be reconciled with similar ligand variability (although only from one cruise), and the inter-basin difference might be explained by differences in hydrothermal inputs suggested by modelling studies (Tagliabue et al., 2010) that await observational confirmation. We find that even in regions where many $\mathrm{dFe}$ measurements ex-
\end{abstract}

ist, the processes governing the seasonal evolution of $\mathrm{dFe}$ remain enigmatic, suggesting that, aside from broad Subantarctic - Antarctic trends, biological consumption might not be the major driver of $\mathrm{dFe}$ variability. This highlights the apparent importance of other processes such as exogenous inputs, physical transport/mixing or $\mathrm{dFe}$ recycling processes. Nevertheless, missing measurements during key seasonal transitions make it difficult to better quantify and understand surface water replenishment processes and the seasonal Fe cycle. Finally, we detail the degree of seasonal coverage by region, basin and depth. By synthesising prior measurements, we suggest a role for different processes and highlight key gaps in understanding, which we hope can help structure future research efforts in the Southern Ocean.

\section{Introduction}

Since the advent of trace metal clean techniques in the late 1970s/early 1980s (e.g., Bruland et al., 1979), the role of iron $(\mathrm{Fe})$ as a key micronutrient that regulates phytoplankton growth rates, primary production and the biological carbon pump in the so-called "High Nutrient Low Chlorophyll" regions of the world's oceans is well established (e.g., De Baar et al., 2005; Boyd et al., 2007). Of these regions, most 
attention has focussed on the Southern Ocean since it is typified by the largest residual stocks of unused macronutrients and plays an important role in governing the global air-sea $\mathrm{CO}_{2}$ balance due to the extensive production of dense deep waters (Caldeira and Duffy, 2000). Indeed, the "Iron Hypothesis" of John Martin (Martin, 1990) posits that the glacial interglacial cycles of atmospheric $\mathrm{CO}_{2}$ recorded in ice cores could have been controlled by changes in the supply of $\mathrm{Fe}$ to the Southern Ocean from aeolian deposition. Phytoplankton production in the modern Southern Ocean is clearly controlled to some degree by $\mathrm{Fe}$, with the highest rates of productivity found alongside known Fe sources such as islands, the Antarctic continental shelf and frontal regions (e.g., Arrigo et al., 2008).

The cycling of $\mathrm{Fe}$ in seawater is complicated, as compared to other macronutrients, and its distribution is controlled by a variety of chemical, physical and biological processes. At the surface, Fe levels are modified due to biological uptake, herbivory and recycling (both biotically and abioticallymediated), but also precipitation and scavenging by particles. Processes such as photochemistry, redox chemistry and dissolution are important drivers of its chemical speciation between soluble (usually $<0.02 \mu \mathrm{m}$ ), colloidal $(0.02-0.2 \mu \mathrm{m})$ and particle $(>0.2 \mu \mathrm{m})$ fractions (e.g., Bowie and Lohan, 2009). A key component governing the cycling and distributions of dissolved $\mathrm{Fe}(\mathrm{dFe},<0.2 \mu \mathrm{m})$ in the ocean is the role of Fe-binding organic ligands. Such ligands complex $\mathrm{Fe}$ in the soluble and colloidal fractions (e.g., Wu et al., 2001; Boye et al., 2010) and reduce losses due to precipitation/scavenging, thereby increasing the residence time of $\mathrm{dFe}$ in the ocean. These processes result in $\mathrm{dFe}$ having a vertical profile that is typical of both a nutrient and a scavenged element (Boyd and Ellwood, 2010). Predominant Fe sources to the Southern Ocean are associated with dust deposition close to continents (e.g., Gaiero et al., 2003; Tagliabue et al., 2009), shallow continental margins (e.g., Blain et al., 2007; Bowie et al., 2009; Pollard et al., 2009; Tagliabue et al., 2009), sea ice melting (e.g., Lannuzel et al., 2008; Van der Merwe et al., 2011), although this acts like a "capacitor" and only transports "new" iron supplied by other sources, and in the deep ocean, hydrothermal vent systems (e.g., Tagliabue et al., 2010).

Due to its acknowledged importance as a limiting nutrient, measurements of $\mathrm{dFe}$ in the ocean, and in the Southern Ocean in particular, have increased markedly over recent years. Advancements in measurement techniques and inter-laboratory comparisons and evaluation projects (e.g., Bowie et al., 2004, 2006; Johnson et al., 2007) have been of major importance. The first compilation of dFe data (354 observations at 30 stations) was performed by Johnson et al. (1997) and then expanded by Parekh et al. (2005), which aided in understanding the importance of scavenging of $\mathrm{dFe}$ in ocean models. More recently, Moore and Braucher (2008) published an expanded database of 6540 observations to aid in the evaluation of their global ocean model. They highlighted novel features in sur- face $\mathrm{dFe}$ concentrations and the importance of the removal of $\mathrm{dFe}$ at low concentrations in subsurface waters as well as the importance of non-aeolian Fe sources (Moore and Braucher, 2008). In recent years, the number of $\mathrm{dFe}$ observations has increased still further, though international programs such as GEOTRACES (www.geotraces.org), especially in regions where sampling was difficult such as the Southern Ocean and the deep ocean. These newer observations in the deep Southern Ocean were recently used to demonstrate the importance of hydrothermal $\mathrm{Fe}$ sources in governing the ocean's deep water $\mathrm{dFe}$ inventory (Tagliabue et al., 2010). Thus, accessible databases of $\mathrm{dFe}$ data compilations are useful for evaluating ocean models, examining the importance of different Fe cycle processes and demonstrating the importance of different Fe sources to the ocean.

In this paper, we present a new compilation of $>13000$ measurements of $\mathrm{dFe}$ in the global ocean for use by the community. We focus on a synthesis and statistical summary of the $>3000$ measurements now available for the Southern Ocean by examining the regional distribution of observations at different depths in this important ocean region. In doing so, we can examine where observations are distributed, what we can learn from them and where future observational efforts are needed. Moreover, we use our database to examine the role of different processes in governing the variability in $\mathrm{dFe}$ between different ocean basins and regions, at different ocean depths, as well as investigating seasonal trends in well sampled locations.

\section{Methodology}

Building on the $\mathrm{dFe}$ dataset collected by Moore and Braucher (2008), which contained 6540 individual observations, we compiled an additional $6585 \mathrm{dFe}$ observations (mostly from recent campaigns) to arrive at a total of 13125 global observations with collection dates that span $30 \mathrm{yr}$ from 1978 to 2008 . The observations used filter pore sizes ranging from $0.2-0.45 \mu \mathrm{m}$ as an operational cut-off for $\mathrm{dFe}$ and are often means from duplicate and triplicate samples. Obviously, a wide range of sampling, processing and analytical techniques have been employed over this 30-yr period (see review of Achterberg et al., 2001). The data were mostly collected by literature review and manual notation of data and submission of data from investigators.

Our focus here is to synthesise the measurements taken in the Southern Ocean in greater depth, since dFe plays a critical role in governing the ocean carbon cycle in this region. To this end, we applied a latitudinal cut off at $40^{\circ} \mathrm{S}$, which approximately corresponds to the Subtropical Front (STF, although we note that this position does vary with longitude), which results in 3332 "Southern Ocean" observations. To further regionalise this variable ocean, we subdivided these 3332 observations using a variety of different criteria. We firstly separated the "shelf" region, since this is often typified 


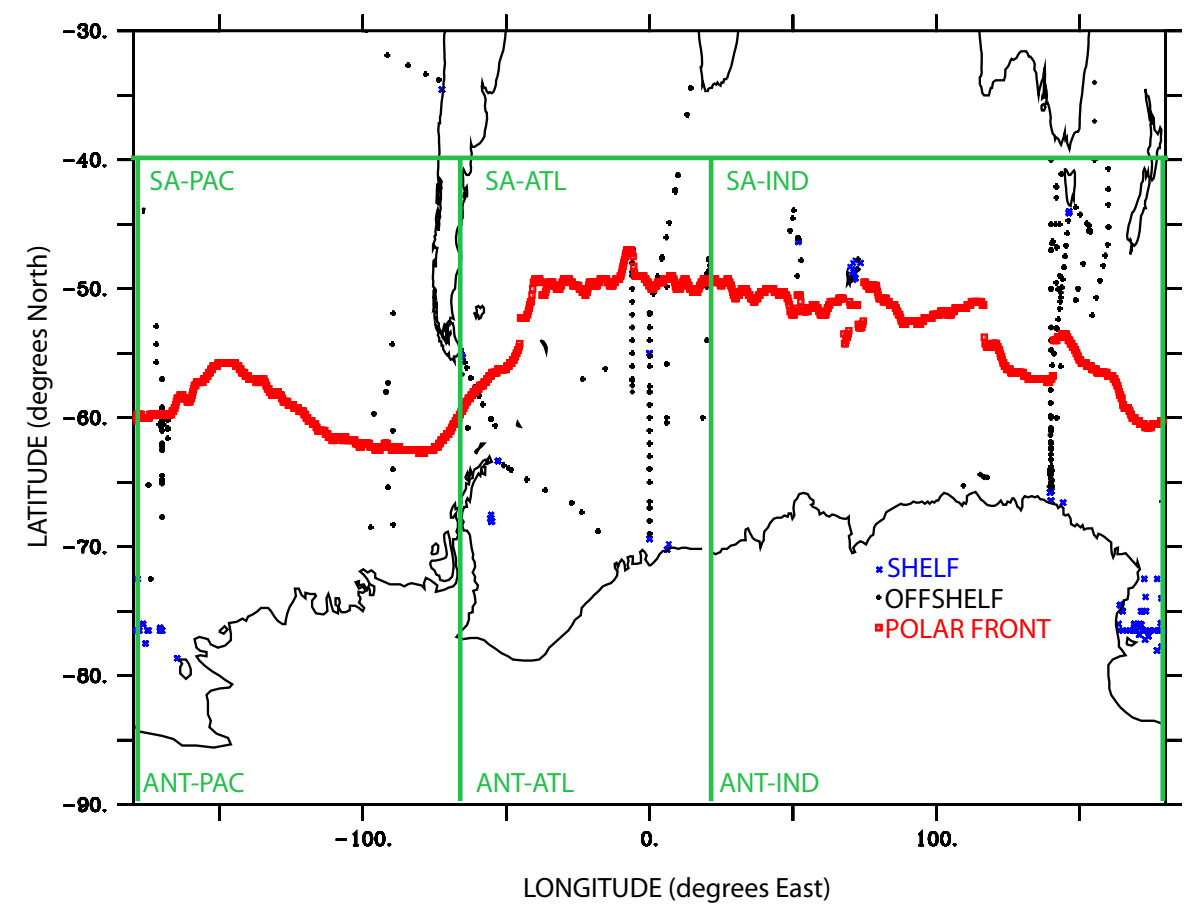

Fig. 1. Distribution of the data and the regional breakdown into different ocean regions and basins.

by high rates of $\mathrm{dFe}$ input (bottom depth $<2000 \mathrm{~m}$ ) from the "off-shelf" region. The "off-shelf" waters were further subdivided into "Antarctic" and Subantarctic' using the northern branch of the polar front (nPF) as a meridional cut-off. The $\mathrm{nPF}$ has a highly variable position as a function of longitude, so we derived the $\mathrm{nPF}$ using maps of absolute dynamic topography, which is the sum of satellite altimetry anomaly data and a mean dynamic topography (Rio and Hernandez, 2004). The nPF is defined using a constant isoline of sea surface height, using a technique first described by Sokolov and Rintoul (2007) (for more details see Swart and Speich, 2010). By analysing the time series of nPF positions between 1998-2008, we determined that the temporal variability in the $\mathrm{nPF}$ at each point in longitude, relative to the mean position used here, to be only $0.72^{\circ} \pm 0.35$. The longitude and latitude of each $\mathrm{dFe}$ observation in "off-shelf" waters was therefore examined as to whether it was north (defined as "Subantarctic") or south (defined as "Antarctic") of the nPF at that particular longitude. Unfortunately, as temperature and salinity changes across the STF can almost compensate for each other at a number of circumpolar regions, the STF often has limited signature in altimetry (e.g., Sokolov and Rintoul, 2007). Therefore, we could not dynamically define the northern limit of the Southern Ocean in a circumpolar fashion in a similar way to the use of the nPF to divide its Subantarctic and Antarctic regions.

The major ocean basins were defined as the Atlantic (ATL, $65^{\circ} \mathrm{W}$ to $20^{\circ} \mathrm{E}$ ), the Indian (IND, $20^{\circ} \mathrm{E}$ to $180^{\circ}$ ) and the Pacific $\left(\mathrm{PAC}, 180^{\circ}\right.$ to $\left.65^{\circ} \mathrm{W}\right)$ all within the "Offshore" region.
In total we used 4 regions ("shelf", "off-shelf", "Antarctic" and "Subantarctic") and 6 basins (ATL-Antarctic, ATL-Subantarctic, IND-Antarctic, IND-Subantarctic, PACAntarctic, PAC-Subantarctic). Within each of these regions and basins, we further subdivided the data into 5 depth ranges $(0-100 \mathrm{~m}, 100-500 \mathrm{~m}, 500-1000 \mathrm{~m}, 1000-2000 \mathrm{~m}$ and $2000-6000 \mathrm{~m}$ ). Our rationale for the depth divisions was based on capturing surface to intermediate to deep water transitions with the goal of arriving at a representative depth profile, as well as retaining a reasonable data density in each depth bin. The distribution of the data as well as the regional break down is shown in Fig. 1. In our analysis, we were interested in examining the variability in $\mathrm{dFe}$ (mean, standard deviation etc.), the number of observations and for which months of the year observations are available.

\section{Results}

\section{1 dFe distributions between regions and basins}

Mean $\mathrm{dFe}$ concentrations versus depth (the midpoint of the particular depth range) for both ocean regions and geographic ocean basins are compiled to examine the variability in $\mathrm{dFe}$ profiles within regions and basins (Fig. 2a and b). Throughout, the distribution of mean $\mathrm{dFe}$ concentration generally behaves like other nutrients/scavenged elements, with low surface water concentrations $(0.1-0.5 \mathrm{nM}$, aside from the shelf region), due to biological uptake that persists below the mixed layer due to scavenging, and increased concentrations 
a)

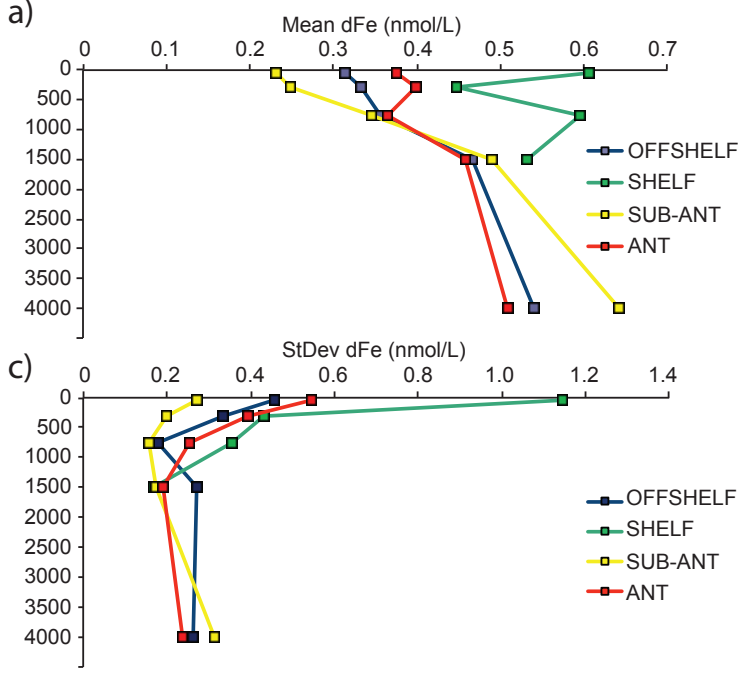

b)

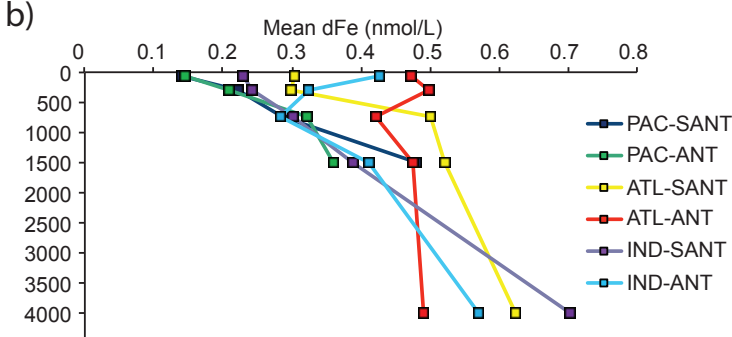

d)

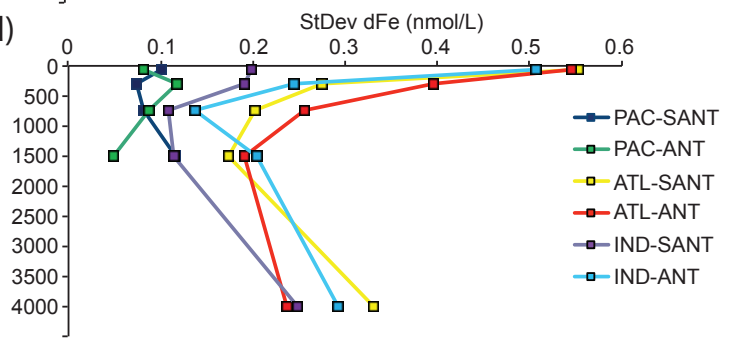

Fig. 2. Mean dFe by (a) region and (b) basin as a function of depth. Standard deviation of dFe measurements by (c) region and (d) basin as a function of depth (we note that $95 \%$ confidence limits lie at twice this value). The points are plotted at the midpoint of the particular depth range.
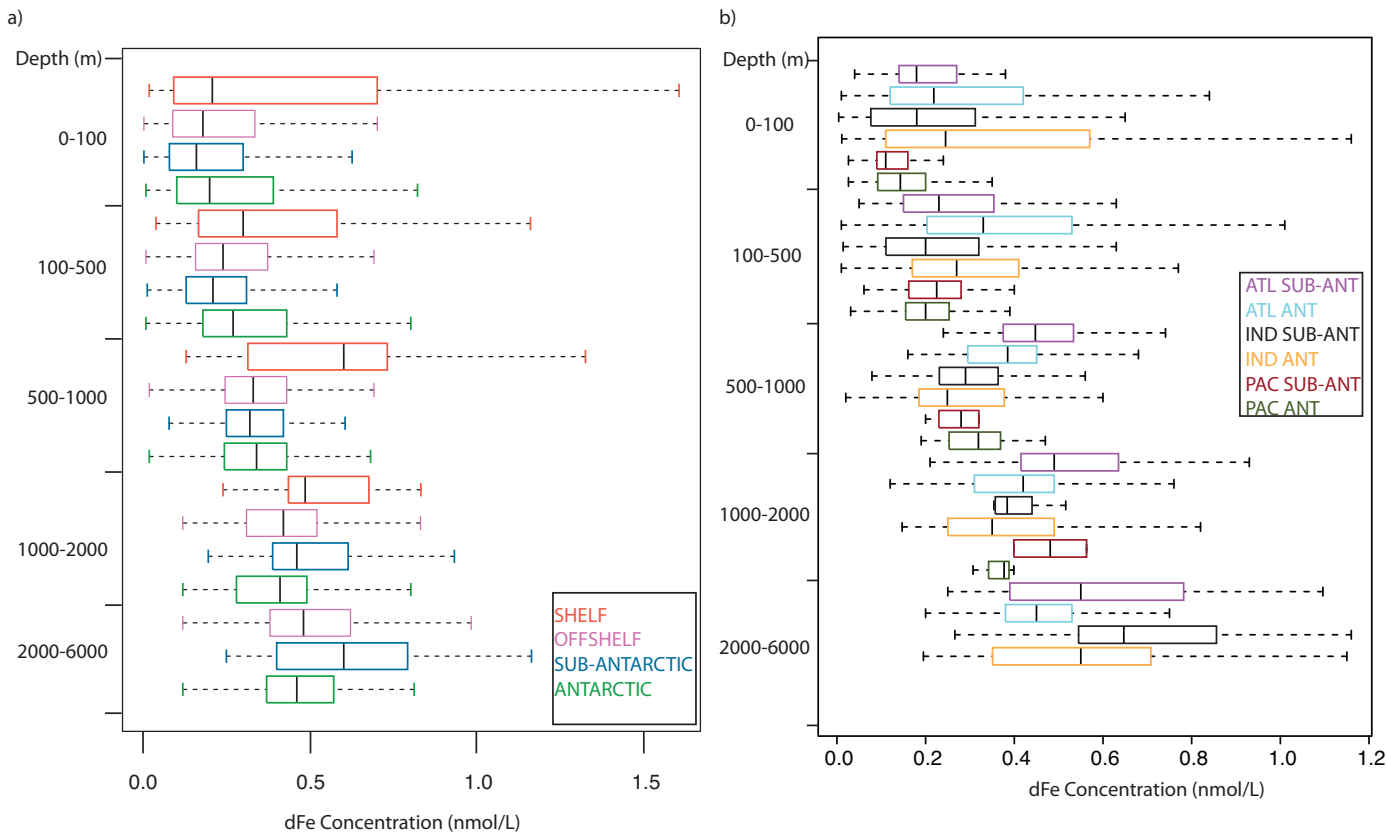

Fig. 3. Box and whisker plots of dFe by (a) region and (b) basin. The size of the box represents the 1st to 3rd quartiles, with the vertical bar corresponding to the median and the whiskers representing 1.5 times the inter-quartile range.

at depth $(>0.4 \mathrm{nM})$ due to remineralisation (Fig. 2a and b, Tables 1 and 2). Nevertheless, there is a great deal of variability between our 4 regions and 6 basins.

Turning first to the different ocean regions (Fig. 2a), the shelf region has a high mean $\mathrm{dFe}$ concentration throughout the water column, with surface water enrichment of $0.61 \pm 1.14 \mathrm{nM}(n=382)$, an intermediate water minimum of $0.60 \pm 0.35 \mathrm{nM}(n=31)$ and deep water values of $0.53 \pm 0.17 \mathrm{nM}(n=20)$. Note that data points below $2 \mathrm{~km}$ were removed by our shelf adjustment/definition. At the other extreme, the off-shelf data show a much clearer nutrient/scavenged element profile, with a surface water minimum of $0.31 \pm 0.45(n=999)$ that increases with depth to $0.54 \pm 0.26 \mathrm{nM}(n=301)$, which is less than the reported concentration of Fe-binding ligands in Southern Ocean deep waters (e.g., $\sim 0.6-1.8 \mathrm{nM}$, Croot et al., 2004; Boye et al., 2010; Ibisamni et al., 2011; Thuroczy et al., 2011), although there are very few ligand data below $1000 \mathrm{~m}$. From within 
Table 1. A summary of the dFe sampling frequency, number of months sampled, number of observations $(N)$ and mean concentration $( \pm$ the standard deviation) for each depth range and Southern Ocean region. We note that, by definition, the $95 \%$ confidence limits lie at twice the standard deviation reported here.

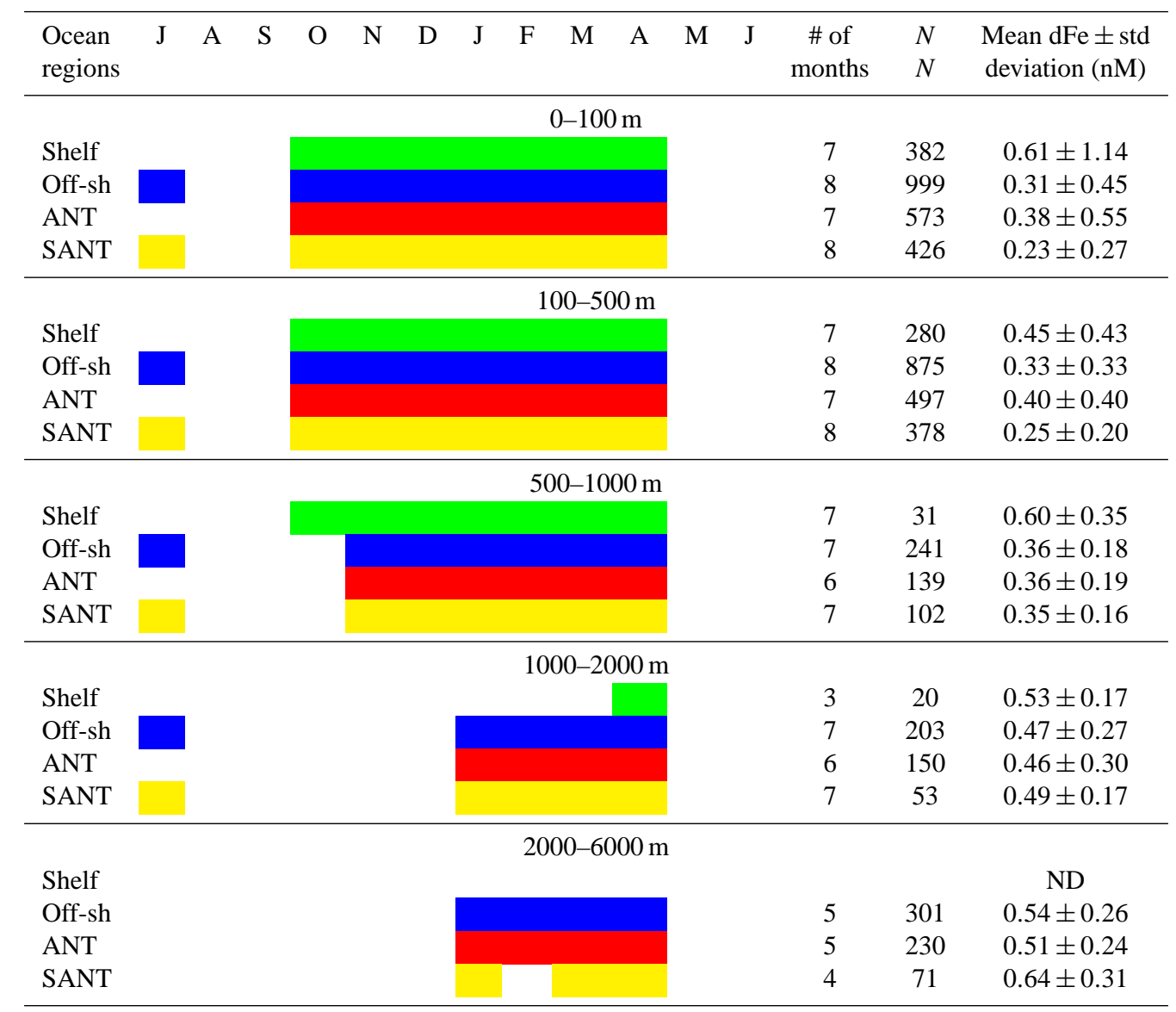

this off-shelf dataset, the Subantarctic observations are lower at the surface $(0.23 \pm 0.27 \mathrm{nM}, n=426$, suggestive of either biological uptake or lesser inputs), but much higher in deep waters $(0.64 \pm 0.31 \mathrm{nM}, n=71)$ and therefore have a much steeper gradient between surface and deep values. On the other hand, the Antarctic region has higher surface concentrations $(0.38 \pm 0.55 \mathrm{nM}, n=573)$, alongside lower deep water values $(0.51 \pm 0.24 \mathrm{nM}, n=230)$ and thus a much flatter profile. The variability in surface values might reflect differences in the degree of productivity, $\mathrm{Fe}$ inputs, inter-annual variability or how much of the seasonal cycle has been measured (see Sect. 3.2), whereas deep water values may reflect regional variability in deep water ligand concentrations or different deep water $\mathrm{Fe}$ sources (e.g., hydrothermal vents; Tagliabue et al., 2010). It is noteworthy that at intermediate depths (for both the 500-1000 and 1000-2000 m depth ranges; Fig. 2a, Table 1) there is no noticeable difference in the mean $\mathrm{dFe}$ concentrations for the Antarctic and Subantarctic regions.

The $\mathrm{dFe}$ measurements show a great deal of intra- and inter-basin variability at all depths across our 6 Southern
Ocean basins (Fig. 2b, Table 2). Surface concentrations in the PAC-Antarctic and PAC-Subantarctic are the lowest we found and very similar for these two regions $(0.15 \pm 0.08 \mathrm{nM}$, $n=141$ and $0.14 \pm 0.10 \mathrm{nM}, n=45$, respectively). Outside of the Pacific, the regional variability noted in Fig. 2a is retained. Both ATL-Subantarctic and IND-Subantarctic are lower than ATL-Antarctic and IND-Antarctic regions, but within each region, the ATL basin is consistently higher than the IND at surface $(0.30 \pm 0.55 \mathrm{nM}, n=58$ and $0.47 \pm 0.69 \mathrm{nM}, n=226$ for ATL-Subantarctic and Antarctic, respectively; $0.23 \pm 0.20, n=323$ and $0.43 \pm 0.51, n=206$ for IND-Subantarctic and Antarctic, respectively; Fig. 2b, Table 2). Again, this could reflect differences in biological activity, surface Fe inputs, or the degree to which the seasonal cycle has been captured in the observations. Conversely, at the deeper depths, the IND basin is always greater than the ATL basin for both Antarctic and Subantarctic regions (Fig. 2b, Table 2). ATL basin intermediate water (500$2000 \mathrm{~m})$ has greatly elevated $\mathrm{dFe}$ concentrations $(\sim 0.4-$ $0.5 \mathrm{nM}$ ) for both Antarctic and Subantarctic regions, relative to IND and PAC basins. Overall, this leads to much steeper 
$\mathrm{dFe}$ profiles in the IND basin because of both lower surface concentrations and higher deep concentrations (relative to the corresponding region of the ATL basin). In the PAC basin, $\mathrm{dFe}$ concentrations increase almost linearly up to a value of $0.48 \pm 0.12 \mathrm{nM}(n=2)$ for Subantarctic and $0.36 \pm 0.05 \mathrm{nM}$ $(n=3)$ for Antarctic in the 1000-2000 m depth bin (unfortunately there are no PAC data deeper than $2000 \mathrm{~m}$ ). At intermediate depth (500-2000 m), the PAC basin shows similar $\mathrm{dFe}$ concentrations to those measured in the IND basin for both the Antarctic and Subantarctic regions. There is a surface enrichment in IND-Antarctic that is robust in the 0 100 and $100-500 \mathrm{~m}$ depth (Fig. 2b) that may be related to the influence of the Antarctic continental shelf sources on $\mathrm{dFe}$ at stations with bottom depths $>2000 \mathrm{~m}$ (e.g., Sedwick et al., 2008). It is also noteworthy that, despite a large number of samples, the ATL-Antarctic shows a very flat profile with little difference in $\mathrm{dFe}$ from surface $(0.47 \pm 0.69 \mathrm{nM}$, $n=226,0-100 \mathrm{~m}$ depth $)$ to deep $(0.49 \pm 0.21 \mathrm{nM}, n=177$, 2000-6000 m depth).

Since we are not considering replicates of identical samples, the standard deviation of the mean $\mathrm{dFe}$ calculated for a particular region or basin is actually better viewed as a metric of the degree of variability in measured $\mathrm{dFe}$ therein. Moreover, as the $95 \%$ confidence limits lie at twice the standard deviation reported here, there is a great deal of variability in our collated dFe measurements. For the different ocean regions (Fig. 2c), the standard deviation typically decreases with depth and is greatest in shelf surface waters $(>1 \mathrm{nM})$. This suggests a greater degree of variability in surface $\mathrm{dFe}$, probably driven by seasonal and interannual trends, and more stable dFe concentrations in deeper waters. Between the Subantarctic and Antarctic regions, the differences in standard deviation mirror those seen for the $\mathrm{dFe}$ concentration (compare Fig. $2 c$ with $2 a)$. Examining the ocean basins, there is more variability at the surface, relative to intermediate waters, but variability increases again between $2000-6000 \mathrm{~m}$ (Fig. 2d). Within this pattern, the IND-Subantarctic shows a consistently lower standard deviation than the ATL basin, and the IND-Antarctic and both regions of the PAC basin (which had the lowest $\mathrm{dFe}$ concentrations) have very low standard deviations. A high standard deviation (seen as the degree of variability) in a particular region/basin or depth range could result from seasonal or inter-annual variability in $\mathrm{dFe}$ or incomplete data coverage where "extreme" observations (e.g., those close to hydrothermal Fe sources, Klunder et al., 2011) have a disproportionate weight.

Figure $3 \mathrm{a}$ and $3 \mathrm{~b}$ present a synthesis of the statistical variability in $\mathrm{dFe}$ for the different ocean basins and regions and as such combine the information present in the different panels of Fig. 2. They highlight regions where dFe is high, but also highly variable (e.g., the shelf between 0$100 \mathrm{~m}$, Fig. 3a). On the other hand, the basin by basin breakdown shows basins where $\mathrm{dFe}$ is low, but varies little (such as the PAC-Subantarctic, $0-100 \mathrm{~m}$ ) or those where $\mathrm{dFe}$ can be high, but with large variability (e.g., IND-Subantarctic, 2000-6000 m).

\subsection{Frequency of sampling for $\mathrm{dFe}$}

\subsubsection{Number of observations}

Tables 1 and 2 summarise the sampling of $\mathrm{dFe}$ and present the number of unique months and number of dFe observations with respect to depth for the 4 regions and 6 ocean basins, respectively. Throughout, all parameters (number of months and observations) decrease with increasing depth regardless of the particular region or basin considered.

In more detail, the shelf region has the lowest number of observations (Table 1), with a maximum of 382 in the upper $100 \mathrm{~m}$. That said, this is still a substantial number of measurements given the relatively small size of this region and results from a long history of repeated field campaigns in particular shelf regions such as the Ross Sea and the Kerguelen Plateau. Considering the off-shelf waters, there are up to $\sim 1000$ observations at the surface, and, in general, there are more observations in the Antarctic region with 573, relative to the Subantarctic region with 426 (apart from the 1000-2000 m depth interval). In the deep ocean (2000-6000 m), there are around 300 measurements in total for off-shelf region, but almost all are concentrated in the Antarctic region (230).

Unsurprisingly, the different ocean basins also display a decreasing number of observations with respect to depth within a specific sector (Table 2). As seen previously, the Antarctic region of a particular basin is generally more sampled than the corresponding Subantarctic region. An exception to this is the IND basin, where its Subantarctic region is better sampled than its Antarctic counterpart. Within the Subantarctic region upper waters $(0-500 \mathrm{~m})$, the PAC basin has less observations (85) than the ATL basin (116), which has less observations than the IND basin (603). For the Antarctic upper waters $(0-500 \mathrm{~m})$, the PAC basin is still the lowest (225, but a factor $\sim 3$ greater than the PAC-Subantarctic), but now the ATL basin has more observations (492, a factor $>4$ greater than the ATL-Subantarctic) than the IND basin (353, which is a factor $\sim 2$ less than the IND-Subantarctic). At depths greater than $500 \mathrm{~m}$, the relatively high degree of sampling in the IND-Subantarctic decreases and the ATLAntarctic becomes the most sampled basin (Table 2). Unfortunately, there are no dFe observations deeper than $2000 \mathrm{~m}$ in the both the Antarctic and Subantarctic regions of the PAC basin.

\subsubsection{Seasonal measurements}

In terms of the seasonal coverage, dFe observations are generally concentrated in the period October to April at best (the austral spring/summer), although there is one set of wintertime observations in July (Tables 1 and 2). On the shelf, observations are available between October to April with 
Table 2. A summary of the dFe sampling frequency, number of months sampled, number of observations $(N)$ and mean concentration $( \pm$ the standard deviation) for each depth range and Southern Ocean basin. We note that by definition, the $95 \%$ confidence limits lie at twice the standard deviation reported here.

\begin{tabular}{|c|c|c|c|c|c|c|c|c|c|c|c|c|c|}
\hline $\begin{array}{l}\text { Ocean } \\
\text { regions }\end{array}$ & $\mathrm{J}$ & A & $\mathrm{S} \quad \mathrm{O}$ & $\mathrm{N}$ & D & $\mathrm{J}$ & F $\quad \mathrm{M}$ & A & M & $\mathrm{J}$ & $\begin{array}{l}\text { \# of } \\
\text { months }\end{array}$ & $\begin{array}{l}N \\
N\end{array}$ & $\begin{array}{c}\text { Mean } d F e \pm \text { std } \\
\text { deviation }(\mathrm{nM})\end{array}$ \\
\hline \multicolumn{14}{|c|}{$0-100 \mathrm{~m}$} \\
\hline PAC SANT & & & & & & & & & & & 5 & 45 & $0.14 \pm 0.10$ \\
\hline PAC ANT & & & & & & & & & & & 5 & 141 & $0.15 \pm 0.08$ \\
\hline ATL SANT & & & & & & & & & & & 5 & 58 & $0.30 \pm 0.55$ \\
\hline ATL ANT & & & & & & & & & & & 6 & 226 & $0.47 \pm 0.69$ \\
\hline IND SANT & & & & & & & & & & & 8 & 323 & $0.23 \pm 0.20$ \\
\hline IND ANT & & & & & & & & & & & 6 & 206 & $0.43 \pm 0.51$ \\
\hline \multicolumn{14}{|c|}{$100-500 \mathrm{~m}$} \\
\hline PAC SANT & & & & & & & & & & & 5 & 40 & $0.22 \pm 0.07$ \\
\hline PAC ANT & & & & & & & & & & & 4 & 84 & $0.21 \pm 0.12$ \\
\hline ATL SANT & & & & & & & & & & & 5 & 58 & $0.30 \pm 0.28$ \\
\hline ATL ANT & & & & & & & & & & & 6 & 266 & $0.49 \pm 0.48$ \\
\hline IND SANT & & & & & & & & & & & 8 & 280 & $0.24 \pm 0.19$ \\
\hline IND ANT & & & & & & & & & & & 5 & 147 & $0.32 \pm 0.24$ \\
\hline \multicolumn{14}{|c|}{$500-1000 \mathrm{~m}$} \\
\hline PAC SANT & & & & & & & & & & & 3 & 10 & $0.28 \pm 0.08$ \\
\hline PAC ANT & & & & & & & & & & & 2 & 16 & $0.32 \pm 0.09$ \\
\hline ATL SANT & & & & & & & & & & & 3 & 24 & $0.50 \pm 0.20$ \\
\hline ATL ANT & & & & & & & & & & & 3 & 76 & $0.42 \pm 0.22$ \\
\hline IND SANT & & & & & & & & & & & 6 & 68 & $0.30 \pm 0.11$ \\
\hline IND ANT & & & & & & & & & & & 4 & 47 & $0.28 \pm 0.14$ \\
\hline \multicolumn{14}{|c|}{$1000-2000 \mathrm{~m}$} \\
\hline PAC SANT & & & & & & & & & & & 1 & 2 & $0.48 \pm 0.12$ \\
\hline PAC ANT & & & & & & & & & & & 1 & 3 & $0.36 \pm 0.05$ \\
\hline ATL SANT & & & & & & & & & & & 3 & 39 & $0.52 \pm 0.17$ \\
\hline ATL ANT & & & & & & & & & & & 3 & 110 & $0.48 \pm 0.33$ \\
\hline IND SANT & & & & & & & & & & & 3 & 12 & $0.39 \pm 0.11$ \\
\hline IND ANT & & & & & & & & & & & 3 & 37 & $0.41 \pm 0.20$ \\
\hline \multicolumn{14}{|c|}{$2000-6000 \mathrm{~m}$} \\
\hline PAC SANT & & & & & & & & & & & & & ND \\
\hline PAC ANT & & & & & & & & & & & & & ND \\
\hline ATL SANT & & & & & & & & & & & 3 & 55 & $0.63 \pm 0.33$ \\
\hline ATL ANT & & & & & & & & & & & 3 & 177 & $0.49 \pm 0.21$ \\
\hline IND SANT & & & & & & & & & & & 2 & 16 & $0.70 \pm 0.25$ \\
\hline IND ANT & & & & & & & & & & & 3 & 53 & $0.57 \pm 0.29$ \\
\hline
\end{tabular}

coverage down to $1000 \mathrm{~m}$, deeper than for observations only available from February to April. There is a similar degree of coverage in off-shelf waters, apart from the Subantarctic region, which has the only winter $\mathrm{dFe}$ observations (in July; Ellwood et al., 2008). Unlike the shelf, October sampling is absent below $500 \mathrm{~m}$ in all off-shelf waters, but July data are present to depths of $2000 \mathrm{~m}$. At depths $>2000 \mathrm{~m}$, there is only coverage from December to April in the off-shelf waters of the Antarctic region, whereas January is absent from the Subantarctic region. In the IND-Subantarctic, there is complete coverage from October to April down to $500 \mathrm{~m}$, below which certain months disappear with only December and
April present deeper than $2000 \mathrm{~m}$. For the IND-Antarctic, March data, as well as the winter data in July, are missing from the October to April coverage at the surface and there is less seasonal coverage than the IND-Subantarctic in intermediate waters. That said, the IND-Antarctic does have data for January in addition to that for December and April present in the IND-Subantarctic basin in the 2000-6000 m depth range. There is lower seasonal coverage throughout the water column of the ATL-Subantarctic; only 5 months (October, December, February, March and April) have been sampled in the upper $100 \mathrm{~m}$, and only February, March and April remain below $500 \mathrm{~m}$ depth. Conversely, there is more seasonal 

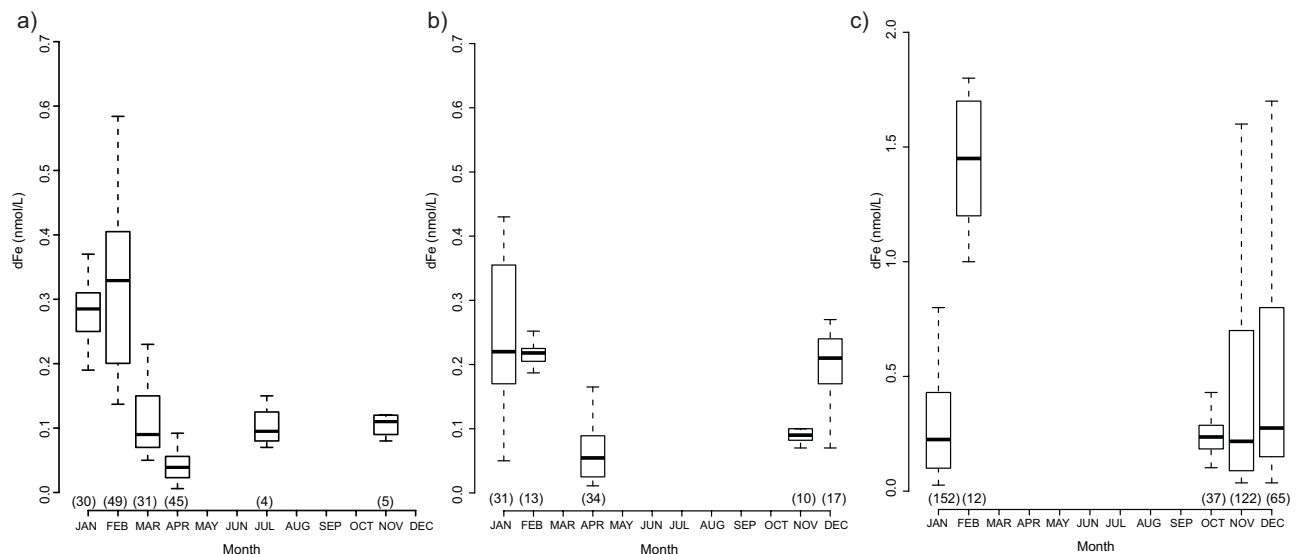

Fig. 4. Box and whisker plots of the seasonal cycle of dFe in the upper $100 \mathrm{~m}$ for (a) the Subantarctic SR3 (164 total observations from 1995-2008), (b) the Antarctic SR3 (105 total observations from 1994-2008) and (c) the Ross Sea (240 total observations from 1990-2008). The SR3 region is defined as that south of $45^{\circ} \mathrm{S}$ and encompassing $135^{\circ} \mathrm{E}$ to $155^{\circ} \mathrm{E}$, and the Ross Sea region is between $155^{\circ} \mathrm{W}$ to $180^{\circ}$. The Subantarctic and Antarctic zones are separated using the mean position of the nPF as illustrated in Fig. 1. The size of the box represents the 1 st to 3rd quartiles, with the vertical bar corresponding to the median and the whiskers representing 1.5 times the inter-quartile range.

coverage in the ATL-Antarctic, with 6 months sampled in the upper $500 \mathrm{~m}$ (December is missing from the October-April period), and below $500 \mathrm{~m}$ only February, March and April have been sampled. Despite the lowest number of total observations (45), the PAC-Subantarctic data still manage to cover 5 months between October-April at the surface (October and February are missing), although the number of months sampled decreases dramatically with depth (in parallel to the decreasing total number of observations). A similar pattern is found in the PAC-Antarctic, with also 5 months sampled at the surface (February and March are missing on this occasion) and a sharp decrease in the number of months sampled in subsurface waters. Overall, despite the great effort made over past decades, knowledge of the dFe distribution (even in surface waters) is completely lacking for the months of May, June, August and September (i.e., the autumn-winter and winter- spring transitions), which may be crucial in understanding the seasonal replenishment and depletion of this important limiting nutrient.

\subsection{Case studies}

Some relatively constrained areas of the Southern Ocean have seen extended efforts of sampling over many years. The two best examples are the SR3 transect south of Tasmania (between 1994-2008) and the southwestern Ross Sea (between 1990-2006) on the Antarctic continental shelf. For surface waters $(0-100 \mathrm{~m})$, there are a total of 294 and 240 observations in our defined "SR3" and "Ross Sea" sectors, respectively (see Fig. 4 legend). Because of the differences between the Antarctic and Subantarctic regions, we further split the "SR3" sector using the mean position of the PF there (see Fig. 1), as well as using a more regionally correct definition of the STF at $45^{\circ} \mathrm{S}$ for this analysis. Overall, this leaves
164 and 105 total observations for the Subantarctic-SR3 and Antarctic-SR3, respectively (or a net total of 269). The seasonal cycle of surface waters $\mathrm{dFe}$ (on a monthly basis) from these three regions (SR3-Subant, SR3-Ant and Ross Sea) was then extracted and is presented in Fig. 4. We note that the dFe data from Lai et al. (2008) had to be excluded from the SR3 analysis (but retained for our larger-scale synthesis), since their dataset was strongly significantly different from other observations from January, February and March (Wilcoxon test, $p<0.0001$ ) and thus biased the monthly $\mathrm{dFe}$ during the austral summer to too high a value.

\subsubsection{SR3}

Climatological satellite derived weekly chlorophyll- $a$ (Chla) for the identical locations in the SR3-Subantarctic and Antarctic sectors for which we have dFe measurements (Fig. 5a and b) shows that Chl- $a$ increases gradually in the SR3-Subantarctic from a (non-zero) winter minimum to maximum values between January and March with a high degree of variability (both spatial and interannual; Fig. 5a), while SR3-Antarctic Chl- $a$ concentrations are lower but with a slightly larger amplitude from winter values and reach a seasonal maximum by late November (Fig. 5b). Superficially, one might expect high Chl- $a$ values to correspond to lower dFe values (due to biological uptake), but for the SR3Subantarctic, the Chl- $a$ maximum in January-February is actually associated with the highest dFe levels (Fig. 4a and 5a), although the Chl- $a$ decline that follows is mirrored in the $\mathrm{dFe}$ concentrations. Higher $\mathrm{dFe}$ associated with high Chl- $a$ could be reconciled by assuming high rates of $\mathrm{Fe}$ recycling associated with greater biomass levels, which then declines as biomass decays into April. It is plausible that the variability in dFe for January-March period (Fig. 4a) is driven 
a)

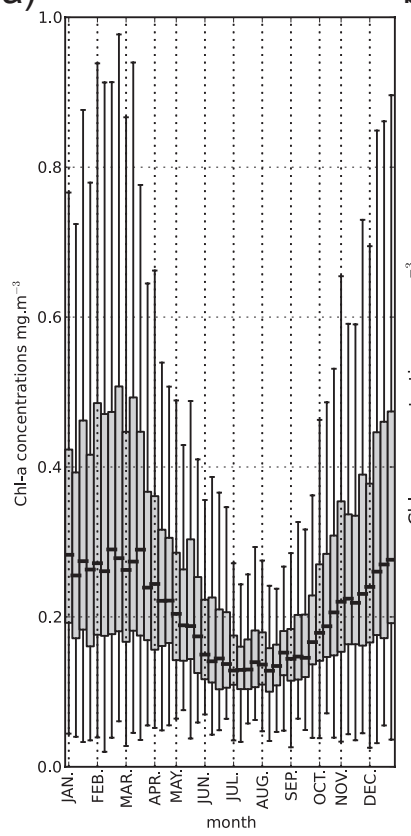

b)

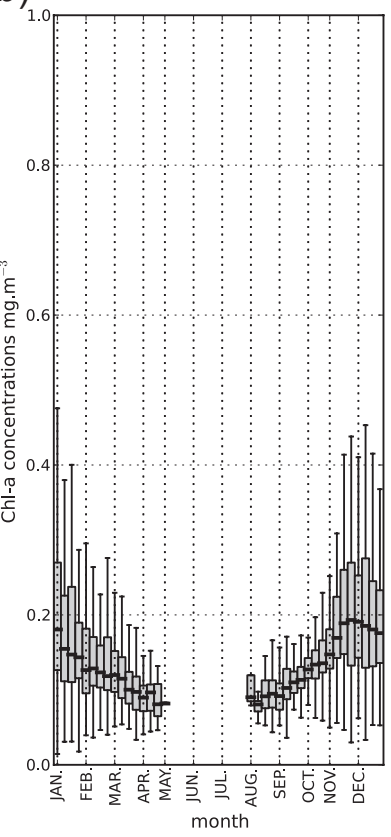

Fig. 5. The mean seasonal cycle in Chlorophyll- $a\left(\mathrm{mg} \mathrm{m}^{-3}\right)$ within our SR3 sector from a climatology of Globcolour ocean colour data over the 1998-2010 period for (a) the Subantarctic and (b) Antarctic. The size of the box represents the 1 st to 3rd quartiles, with the vertical bar corresponding to the median and the whiskers representing 1.5 times the inter-quartile range.

by similar inter-annual variability in Chl- $a$ over this period (Fig. 5a) by its influence on dFe consumption/recycling; alternatively, both $\mathrm{dFe}$ and Chl- $a$ might be connected to variability in $\mathrm{dFe}$ inputs. For the SR3-Antarctic, the November maximum in Chl- $a$ corresponds to a minimum in $\mathrm{dFe}$ of $\sim 0.14 \mathrm{nM}$ (Figs. 4b and 5b, Sedwick et al., 2008), but dFe then increases through the December-February period before declining again by April (Fig. 4b), while Chl- $a$ levels fall over the same period (Fig. 5b). Despite the mean seasonal trend, Chl- $a$ values are highly variable across the NovemberApril period (Fig. 5b) and this could preclude the presence of a distinct seasonal trend in $\mathrm{dFe}$. Nevertheless, the general positive covariation of Chl- $a$ values and dFe concentration (the putative limiting nutrient) over the growing season (presented in Figs. 4a-b and 5a-b) is somewhat surprising and might indicate that the dominant driver of $\mathrm{dFe}$ variability is not phytoplankton consumption as alluded to by Chl- $a$, but rather $\mathrm{dFe}$ recycling, exogenous inputs and/or mixed layer depth dynamics (see Sect. 4.4).

An important aspect of the seasonal cycle from the SR3 Subantarctic sector is the presence of the only Southern Ocean measurements of $\mathrm{dFe}$ in the austral winter of $\sim 0.1 \mathrm{nM}$ in the upper $100 \mathrm{~m}$ (Ellwood et al., 2008), although slightly to the east of the "classic" SR3 line. Within the paradigm of a winter "reset" of $\mathrm{dFe}$ levels by vertical mixing, these val-

ues are initially surprisingly low. July concentrations are only slightly higher than values of $\sim 0.05 \mathrm{nM}$ in April (Bowie et al., unpublished data), similar to the SR3-Antarctic in April, and November concentrations are only $\sim 0.14 \mathrm{nM}$ (Sedwick et al., 2008). Thus, there is a gradual trend of only a slight increase in $\mathrm{dFe}$ from $0.05 \mathrm{nM}$ in April, to $0.1 \mathrm{nM}$ in July and $0.14 \mathrm{nM}$ in November that is followed by much higher values in January and February (to $\sim 0.35 \mathrm{nM}$, Fig. 4a) that tracks the Chl- $a$ trend (Fig. 5a). Taken at face value, this suggests that the "reset" of dFe concentrations in the Subantarctic region of the SR3 sector might actually be a springtime phenomenon (i.e., occurring after November), possibly driven by atmospheric Fe deposition, vertical supply or advection of subtropical waters (via the east Australian Current extension, which is particularly important for samples in the northern part of our SR3 Subantarctic sector) into the Subantarctic region (Boyd et al., 2004; Ellwood et al., 2008; Sedwick et al., 2008; Bowie et al., 2009). Biological activity in January and February then depletes these values to $\sim 0.23 \mathrm{nM}$ in March (Sedwick et al., 2008) and then to their April minimum levels. However, it is important to note that there are no measurements between July and November, a period over which Chl- $a$ levels show an increasing trend (Fig. 5a), which suggests some dFe re-supply is not altogether unlikely. Indeed, seasonal mixed layer depth climatologies suggest that the deepest mixed layers in this region are actually in the August-September period (de Boyer-Montegut et al., 2004), although rarely deeper than $300 \mathrm{~m}$. Thus, it appears plausible that there is some increase in $\mathrm{dFe}$ between July and November due to vertical mixing that is then further augmented by other $\mathrm{dFe}$ sources (either dust, subtropical water, recycling or further vertical mixing) in January and February. For example, Sedwick et al. (2008) have noted the influence of continental air masses deep into the SR3-Subantarctic sector in January, while samples in the northern part of this sector will have $\mathrm{dFe}$ inputs from subtropical water (Bowie et al., 2009). Regardless of its timing, any vertical mixing over winter would have to mix sufficiently deeply to reach the deep ferriclines typical of this region $(\sim 500 \mathrm{~m}$, Sedwick et al., 2008 ; Bowie et al., 2009) in order to act as a significant mechanism of seasonal dFe resupply. The absence of winter observations from the SR3-Antarctic sector means that it is not possible to assess whether (or not) the winter dFe value is higher than that measured in the SR3-Subantarctic in July or how, when and if surface water $\mathrm{dFe}$ stocks are replenished in order to fuel biological production in the subsequent growing season. Only new dFe observations from the autumn-winter-spring transition period can help resolve these questions. Using the vertical profiles from Fig. $2 b$, our synthesis would suggest that the maximum possible "winter reset" to dFe concentrations in this region would only be around $0.3 \mathrm{nM}$ at most (i.e., the maximum values in the $100-500$ and $500-1000 \mathrm{~m}$ depth bins; Fig. 2b, Table 2). 


\subsubsection{The Ross Sea}

The high degree of variability in the magnitude and timing of the seasonal cycle of phytoplankton biomass in the Ross Sea is mirrored by a large degree of variability in $\mathrm{dFe}$, where numerous observations (over the period 1990-2006) have been made. Median $\mathrm{dFe}$ concentrations are low $(<0.25 \mathrm{nM})$ throughout the November to January period, but are associated with high variability for, in particular, the months of November and December (Fig. 4c). The central Ross Sea polynya is normally associated with a bloom of Phaeocystis antarctica that displays a peak in December, but shows variability associated with the timing and extent of open water over the period (Arrigo and Van Dijken, 2004). The dFe observations span the period 1990-2008 and thus encompass years typified by large anomalies in the timing and magnitude of the phytoplankton bloom that are primarily driven by variable sea-ice dynamics due to El Niño (1997/1998, Arrigo and Van Dijken, 2004) and the discharge of large icebergs (2000/2001 and 2002, Arrigo et al., 2002, Arrigo and Van Dijken, 2003), as well as the location of sampling (e.g., bottom depth, vicinity to melting sea ice; Sedwick et al., 2011). Thus, the variability in measurements of $\mathrm{dFe}$ in November and December (which both contain observations spanning 1994-2006) includes years of early and intense blooms, as well as years with delayed and low biomass blooms, thus driving a high degree of variability in $\mathrm{dFe}$ (Fig. 4c). Moreover, studies that sampled near known Fe sources (sea ice, shallow bathymetry), as compared to those undertaken in open, probably Fe depleted (Sedwick et al., 2011), polynya waters also contributes to dFe variability. Accordingly, the high dFe values for February (Grotti et al., 2001) are probably more indicative of sampling close to fast ice rich in continental $\mathrm{Fe}$, rather than a seasonal trend. Nevertheless, $\mathrm{dFe}$ values can remain low throughout the period OctoberJanuary (Fig. 4c), which is indicative of a rapid utilisation of the winter reservoir (Sedwick et al., 2011). Reconciling low $\mathrm{dFe}$ values in November, with a biomass peak around December, led Sedwick et al. (2011) to speculate about additional Fe sources during this period. Nevertheless, a constraint on the seasonal maxima in $\mathrm{dFe}$, which is critical in calculating seasonal depletion, remains lacking at both the start and end of the growing season. Regional model results suggest that convective overturn in winter will cause a winter maximum in $\mathrm{dFe}$ (Tagliabue and Arrigo, 2006, unlike the SR3-Subantarctic, Sect. 3.3.1), but there are no observations later than February (i.e., after the major peak in productivity). Given the large body of dFe observations already collected in the Ross Sea (already 240 between $0-100 \mathrm{~m}$ ) and the information gained regarding the importance of a variety of processes in connecting $\mathrm{dFe}$ cycling to phytoplankton productivity, we would hope that future studies (especially those aimed at constraining the seasonal maxima in $\mathrm{dFe}$ ) will continue in order to better understand the seasonal cycle of $\mathrm{dFe}$ in this important natural laboratory for Southern Ocean systems.

\section{Discussion}

\section{1 dFe distribution and processes}

Overall, surface dFe is higher in the Antarctic region than the Subantarctic region, while within each of these regions the ATL basin is characterised by higher dFe than the IND basin. We speculate that these differences relate to differing levels of biological activity and the degree of Fe inputs. The Southern Ocean primary productivity (PP) estimates of $\mathrm{Ar}-$ rigo et al. (2008) show greater rates of PP in the Subantarctic region $\left(>100 \mathrm{gC} \mathrm{m}^{-2} \mathrm{a}^{-1}\right)$, relative to the Antarctic region $\left(<100 \mathrm{gC} \mathrm{m}^{-2} \mathrm{a}^{-1}\right)$, suggesting that higher surface $\mathrm{dFe}$ in the Antarctic region (Fig. 1a, Table 1) might result from lower rates of biological activity (most likely due to sea ice cover/reduced open water duration and low light levels for half of the year), with the opposite true for the Subantarctic. It is also plausible that the upwelling of upper circumpolar deep water (UCDW) that is enriched with deep-water $\mathrm{dFe}$ in the Antarctic region is depleted during its Ekman transport northwards to the Subantarctic region (Hoppema et al., 2003), thus also contributing to the inter-region surface $\mathrm{dFe}$ differences and lowering the Antarctic region's PP. Turning to geographic regions, Arrigo et al. (2008) report mean annual PP of $70.2 \mathrm{gC} \mathrm{m}^{-2} \mathrm{a}^{-1}$ for their Weddell Sea geographic sector (which closely corresponds to the area of our ATL basin), while the combined mean PP of the South Indian Ocean and Southwest Pacific Ocean sectors (which encompass most of our IND basin) was $\sim 46 \mathrm{gC} \mathrm{m}^{-2} \mathrm{a}^{-1}$ (Arrigo et al., 2008). Thus, it appears that PP is most likely higher in the ATL, relative to the IND basin, and high ATL basin $\mathrm{PP}$ is associated with higher $\mathrm{dFe}$ concentrations in surface waters (Fig. 2b, Table 2). So while the low $\mathrm{dFe}$ of the Subantarctic region is associated with high PP, the opposite is true when inter-basin trends are compared (low $\mathrm{dFe}$ in the IND basin corresponds to lower PP), which suggests that $\mathrm{PP}$ rates alone cannot explain inter-basin differences in $\mathrm{dFe}$. Thus, when combined with our evidence from the SR3 region (Sect. 3.3.1), it appears that biological consumption is not able to explain the seasonal or inter-basin $\mathrm{dFe}$ trends since either PP or Chl- $a$ covary positively with $\mathrm{dFe}$.

Inter-basin trends in surface $\mathrm{dFe}$ from our synthesis might better reflect differences in the degree of Fe inputs. Since PP differences between the ATL and IND basins are opposite to what one might anticipate explaining the $\mathrm{dFe}$ trends, we must examine whether other processes might be at work. The obvious remaining candidate is that the ATL basin receives higher rates of Fe input than the IND basin, so that despite higher rates of PP, the ATL basin is still typified by higher surface $\mathrm{dFe}$ concentrations. The major sources of $\mathrm{Fe}$ to Southern Ocean surface waters are dust deposition and supply from shallow continental margins, as well as seasonal melting of sea-ice (e.g, Lannuzel et al., 2008; Tagliabue et al., 2009; Van der Merwe et al., 2011). For example, the ATL basin is close to Patagonian dust sources of Fe (e.g., Gaiero 
et al., 2003), as well as the large Patagonian plateau and associated rivers and glaciers, the continental margins of the numerous islands present in the ATL basin, and the Antarctic Peninsula (e.g., Boyd and Ellwood, 2010; Klunder et al., 2012). Additionally, higher rates of upper ocean eddy kinetic energy (eddy genesis and meandering, EKE) in the South Atlantic are caused by current convergence/divergence predominantly at the Brazil-Malvinas Confluence (Maamaatuaiahutapu et al., 1998; Peterson and Stramma, 1990), the Agulhas Current retroflection and over the Atlantic mid-ocean ridge (Swart and Speich, 2010). Higher EKE provides a plausible mechanism whereby deeper waters with higher Fe concentrations can be supplied to the euphotic zone through upwelling processes (Archer and Johnson, 2000; Lévy et al., 2001; Klein and Lapeyre, 2009). On the other hand, the INDbasin's dust sources are at more northerly latitudes and only the Kerguelen Plateau and the Tasmanian shelf are potential margin sources (e.g., Bowie et al., 2009; Boyd and Ellwood, 2010), which may mean that this basin receives less exogenous input of $\mathrm{dFe}$. Therefore, we speculate that while the inter-region differences in $\mathrm{dFe}$ can be explained by higher PP rates in the Subantarctic region, the inter-basin differences are due to the greater Fe inputs, both exogenous and vertical, experienced in the ATL basin.

Opposite to the surface trends, the deep Subantarctic region has higher $\mathrm{dFe}$ than the Antarctic region, and within each region, the IND basin is now greater than the ATL. These differences could result from variability in the concentrations of Fe-binding ligands in the deep ocean, or differing degrees of $\mathrm{Fe}$ inputs from deep sources such as hydrothermal vents. There are of course not as many measurements of $\mathrm{Fe}$ ligands as for $\mathrm{dFe}$, and subtle methodological issues (e.g., different detection windows) can complicate intermethod comparisons (e.g., Hudson et al., 2003). Thuroczy et al. (2011) report measurements from both the Subantarctic and Antarctic regions of the ATL basin. At depths of $\sim 4 \mathrm{~km}$, ligand concentrations were $\sim 1 \mathrm{nM}$ in the Subantarctic ATL, while the Antarctic ATL concentrations were only $\sim 0.7 \mathrm{nM}$ (Thuroczy et al., 2011), which matches well with our higher deep dFe in the ATL-Subantarctic as compared to the ATL-Antarctic (Fig. 2b, Table 2). Interestingly, Thuroczy et al. (2011) found ligand concentrations $>1 \mathrm{nM}$ in the intermediate waters of their ATL Subantarctic stations, which corresponds well with the increased intermediate depth $\mathrm{dFe}$ (Fig. 2b, Table 2). If these inter-region differences in ligand concentrations were consistent across the Southern Ocean, then it appears that variability in ligands might dictate deep $\mathrm{dFe}$ trends between the Subantarctic and Antarctic regions (Fig. 1a, Table 1). In the Subantarctic region, the higher deep water values of Thuroczy et al. (2011) from the ATL $(\sim 1 \mathrm{nM})$ and the deepest samples at $1000 \mathrm{~m}$ by Ibisanmi et al. (2011) in the IND basin $(0.58-0.83 \mathrm{nM})$ suggest that the increasing $\mathrm{dFe}(>2000 \mathrm{~m}$ depth) trend between the ATL-Subantarctic and the IND-Subantarctic is not reflected by a similar increasing trend in ligand concentrations (although we draw attention to the different detection windows used in each study). This may mean that inter-basin differences between the ATL and IND reflect different Fe inputs. The only plausible inputs at these depths are associated with hydrothermal activity, and indeed the hydrothermal Fe fluxes proposed by Tagliabue et al. (2010) do show greater inputs in the IND basin, relative to the ATL basin, due to the faster spreading rates of hydrothermal systems in the IND basin, which results in greater $\mathrm{dFe}$ input. Nevertheless, this is a speculation based on the assumption that hydrothermal dFe inputs reflect the rate of ridge spreading that necessitates local $\mathrm{dFe}$ observations. Overall, this suggests that the greater deep $\mathrm{dFe}$ in the Subantarctic region is related to greater concentrations of Fe-binding ligands, while $\mathrm{dFe}$ concentrations are increased in the deep IND basin due to more hydrothermal activity. If remineralisation of organic matter is a ligand source (Ibisanmi et al., 2011), then greater ligand concentrations in the Subantarctic region are consistent with the region's higher PP. In the PAC basin, where hydrothermal inputs are proposed to be greatest, we lack the deep dFe data to investigate the potential importance of this Fe source. A plausible additional explanation for the different vertical profiles is that the upwelling of Fe-enriched UCDW (Hoppema et al., 2003) in the ATL basin causes a flatter profile than the IND.

\subsection{Sampling frequency and seasonality}

In the past decades, a large number of $\mathrm{dFe}$ measurements have been collected that provide seasonal variability data in the Southern Ocean (e.g., Martin et al., 1990; de Baar et al., 1995, 1999; Löscher et al., 1997; Lannuzel et al., 2011; Fitzwater et al., 2000; Sedwick et al., 1997, 1999, 2000, 2008, 2011; Sohrin et al., 2000; Measures and Vink, 2001; Bowie et al., 2004, 2009; Coale et al., 2005; Chever et al., 2010, Klunder et al., 2011). However, despite these efforts, there are some months in different ocean regions and basins in which no dFe measurements have yet been made. Our synthesis (Tables 1 and 2) shows that there is general coverage from October to April, but, apart from one set of observations in the IND-Subantarctic from July, no measurements outside of this period. By basin, the PAC stands out as having the lowest number of observations in total and no measurements whatsoever below $2000 \mathrm{~m}$. That said, it has similar seasonal coverage to the ATL basin in the upper water column $(0-1000 \mathrm{~m})$. It is also notable that the ATL basin has no measurements in November and January (for the Subantarctic) or December (for the Antarctic), despite this being in the austral summer period.

While acknowledging the difficulty of sampling for $\mathrm{Fe}$ outside of the austral spring-summer-autumn period, the lack of observations from the winter-spring and autumnwinter "transition" periods, as well as the winter in general, can hinder attempts to understand the Southern Ocean $\mathrm{Fe}$ cycle. For example, given the seasonal cycle in $\mathrm{dFe}$, missing months can bias the mean $\mathrm{dFe}$ we calculate by 
basin and region, which may have implications for the processes thought to be governing $\mathrm{dFe}$ distributions. In addition, $\mathrm{dFe}$ measurements are now being used to evaluate the performance of complex ocean biogeochemical models (e.g., Moore and Braucher, 2008; Tagliabue et al., 2010), but if no observations are available outside of the October-April period, then the model is not assessed at these times. In practise, this means that the models are only compared when $\mathrm{dFe}$ levels are relatively low in the growing season and the maximum $\mathrm{dFe}$ concentrations (which likely occur outside of this period) cannot be constrained. This is important, because it means that the "winter stock" of dFe in a given model, which more or less dictates the total net primary productivity achievable, cannot be compared to observations. Finally, our case studies from the SR3 and Ross Sea sectors of the Southern Ocean show that the lack of measurements from the winter-spring and autumn-winter "transition" periods results in a poorly constrained seasonal cycle. Most importantly, the only winter measurements from the Southern Ocean appear to contradict the paradigm of a winter reset in $\mathrm{dFe}$ concentrations (at least for the IND-Subantarctic) and highlight the need of obtaining $\mathrm{dFe}$ measurements in this difficult period of the year for sampling.

As months of the year (or specific basins) without dFe observations leave us with difficulties in understanding the seasonality of $\mathrm{dFe}$ in the Southern Ocean, we propose that our synthesis can help target future $\mathrm{dFe}$ observations. We would argue that a major priority, regardless of location, should be to obtain any measurements outside of the wellsampled October-April period. Targeting the seasonal transitions, when the system is in "flux", appears to be important in understanding how stocks of $\mathrm{dFe}$ are replenished for subsequent growing seasons. This may be best achieved through mooring programs such as the Southern Ocean Time Series (SOTS), if such mission can return clean samples collected on a weekly-to-biweekly basis to shore-based laboratories for analysis (Trull et al., 2010). Poorly sampled regions, such as the PAC basin in general and the ATL for some months, would also be important to better characterise interbasin variability in the sources and cycling of dFe. For example, if hydrothermal sources are indeed important, then the largest signal of this should be in the deep PAC basin (Tagliabue et al., 2010), where observations are, up to now, absent. Nevertheless, significant dFe enrichment was observed in Southeast Pacific deep slope water masses near Drake Passage that have transited from the east Pacific rise, which would be supportive of high rates of hydrothermal dFe input in the deep PAC basin (Klunder et al., 2012).

\subsection{Comparing recent $\mathrm{dFe}$ measurements with early determinations}

Over the 1989-2008 period, for which we have synthesised Southern Ocean $\mathrm{dFe}$ measurements, there has been a steady convergence of techniques and ever improving precision. For example, limits of detection of early Fe techniques were of the order of $0.1 \mathrm{nM}$ (e.g., Achterberg et al., 2001; Bruland and Rue, 2001), whereas more recently methodologies permit dFe concentrations $<0.05 \mathrm{nM}$ to be precisely determined (Bowie et al., 2006; Klunder et al., 2011). In addition, intercalibration projects such as IRONAGES (Bowie et al., 2006), and SAFE (Johnson et al., 2007) resulted in a number of improvements in protocols and SAFE, in particular, produced a surface and deep water "reference" sample for which the concentrations had been precisely determined, which has proved invaluable for scientists to "validate" new methods. Finally, the advent of clean sampling rosettes (e.g., Measures et al., 2008) for trace metals that are capable of deep-water deployments has also played an important role in the collection of contamination-free samples. New intercalibration efforts under the GEOTRACES program are continuing to improve our ability to produce high quality $\mathrm{dFe}$ data in the open-ocean. Because of these issues, we were interested in examining whether there has been a statistical difference in the properties of the $\mathrm{dFe}$ measurements between earlier observations that had higher detection limits and no reference samples, against more recently collected $\mathrm{dFe}$ data. To that end, we split our Southern Ocean dFe dataset into two subsets: one containing measurements from 1989-2002 (a total of 1458 observations) and the other from 2003-2008 (a total of 1874 observations), which were then subdivided into the shelf, offshelf, Antarctic and Subantarctic regions, as well as across the 5 depth ranges as previously described (see Fig. 1; further subdivision by basin would have risked having too few data for each time frame).

Table 3 presents the results of a Wilcoxon/Mann Whitney test between the 1989-2002 and the 2003-2008 dFe data by region and depth range. In the upper $500 \mathrm{~m}, 1989-2002$ $\mathrm{dFe}$ data were significantly lower than data measured between 2003-2008 for all regions except the Subantarctic. In the shelf region, 1989-2002 dFe was much higher between 0-100 $\mathrm{m}$ than that derived from 2003-2008 data (means of 0.898 and $0.292 \mathrm{nM}$, respectively, Table 3). For off-shelf waters and the Antarctic region, $0-100 \mathrm{~m}$ dFe concentrations were on the order of $0.1 \mathrm{nM}$ lower in 2003-2008 observations, relative to 1989-2002, with similar offsets in the 100$500 \mathrm{~m}$ depth interval (Table 3). On the other hand, the deepest samples (depths $>1000 \mathrm{~m}$ ) showed no significant differences between 1989-2002 and 2003-2008, while the off-shelf and Subantarctic regions showed significantly higher $\mathrm{dFe}$ from 2003-2008, relative to 1989-2002, in intermediate waters (500-1000 m, mean differences of $\sim 0.06-0.07 \mathrm{nM}$, Table 3). In surface waters the degree of difference is at some degree due to the "process"-based nature of earlier cruises as compared to the more recent "section"-based cruises of the GEOTRACES era. Comparing old and new data in any greater detail is problematic due to complex methodological factors (for example, differences in the degree and length of acidification). Finally, it is also worth drawing attention to the fact that the 2003-2008 dataset (especially in the deep ocean) 
Table 3. Differences in the distribution of dFe data collected between 1989-2002 and 2003-2008 are tested using the Wilcoxon/Mann Whitney test for non-parametric data by region and depth. The statistical significance or $p$-value associated with the difference in location parameters (where a positive value indicates greater dFe in the 1989-2002 date of collection subset) is as follows: ${ }^{\mathrm{NS}}=p>0.1$ (or deemed "not significant"), ${ }^{*}=0.1 \geq p>0.05,{ }^{* *}=0.05 \geq p>0.01,{ }^{* * *}=0.01 \geq p<0.001,{ }^{* * * *}=p<0.001$. To aid clarity, negative differences in the location parameter are in italics, and $p$ values $\leq 0.01$ (i.e., highly significant) are in bold. "ND" indicates where there were not enough data to perform the statistical test. Also reported is the mean dFe concentration (with the number of observations in parentheses) for each region/depth.

\begin{tabular}{llrrr}
\hline Region & $\begin{array}{l}\text { Depth range }(\mathrm{m}) \\
\text { Depth range }\end{array}$ & $\begin{array}{r}\text { Difference in } \\
\text { location }(\mathrm{nM})\end{array}$ & $\begin{array}{r}\text { Mean dFe } \\
(\mathrm{nM}, 1989-2002, n)\end{array}$ & $\begin{array}{r}\text { Mean dFe } \\
(\mathrm{nM}, 2003-2008, n)\end{array}$ \\
\hline Shelf & $0-100$ & $\mathbf{0 . 1 7 1}^{* * * *}$ & $0.898(198)$ & $0.292(184)$ \\
Off-shelf & & $\mathbf{0 . 0 4 8}^{* * * *}$ & $0.354(555)$ & $0.27(444)$ \\
SUBANTARCTIC & & $0^{\mathrm{NS}}$ & $0.244(185)$ & $0.221(241)$ \\
ANTARCTIC & & $\mathbf{0 . 0 8 0}^{* * * *}$ & $0.409(370)$ & $0.317(203)$ \\
Shelf & $100-500$ & $\mathbf{0 . 0 9 0}^{* * * *}$ & $0.541(144)$ & $0.350(136)$ \\
Off-shelf & & $\mathbf{0 . 0 6 0}^{* * * *}$ & $0.400(401)$ & $0.278(474)$ \\
SUBANTARCTIC & & $0.040^{* *}$ & $0.308(132)$ & $0.217(246)$ \\
ANTARCTIC & & $\mathbf{0 . 0 5 0}^{* * *}$ & $0.444(269)$ & $0.345(228)$ \\
Shelf & $500-1000$ & $0.256^{*}$ & $0.820(9)$ & $0.503(22)$ \\
Off-shelf & & $-\mathbf{0 . 0 5 3}^{* * *}$ & $0.301(62)$ & $0.376(179)$ \\
SUBANTARCTIC & & $-0.040^{\mathrm{NS}}$ & $0.296(20)$ & $0.358(82)$ \\
ANTARCTIC & & $-\mathbf{0 . 0 6 2} 2^{* * *}$ & $0.303(42)$ & $0.39(97)$ \\
Shelf & $1000-2000$ & $\mathrm{ND}$ & $\mathrm{ND}(0)$ & $0.532(20)$ \\
Off-shelf & & $-0.010^{\mathrm{NS}}$ & $0.453(42)$ & $0.469(161)$ \\
SUBANTARCTIC & & $-0.068^{\mathrm{NS}}$ & $0.419(6)$ & $0.499(47)$ \\
ANTARCTIC & & $0.012^{\mathrm{NS}}$ & $0.458(36)$ & $0.458(114)$ \\
Off-shelf & $2000-6000$ & $0.060^{*}$ & $0.607(47)$ & $0.528(254)$ \\
SUBANTARCTIC & & $0.270^{* *}$ & $0.870(6)$ & $0.622(65)$ \\
ANTARCTIC & & $0.0500^{\mathrm{NS}}$ & $0.568(41)$ & $0.495(189)$ \\
\hline
\end{tabular}

always has many more dFe observations than the 1989-2002 dataset, despite covering a much smaller time period. This is striking evidence of the progress being made in collecting $\mathrm{dFe}$ samples from the Southern Ocean as part of the International Polar Year and ongoing GEOTRACES efforts.

\subsection{Future challenges}

In the future our $\mathrm{dFe}$ dataset should be augmented by appropriate metadata such as temperature, salinity and macronutrient information. Unfortunately, this was not possible for the entire dFe historical dataset at this stage. If such associated information were available, the unprecedented $\mathrm{dFe}$ data coverage we compile here could be used alongside metadata to understand the possible role for a number of different $\mathrm{Fe}$ cycle processes in governing the Southern Ocean dFe cycle. For example, interesting avenues (Croot, 2012) could be to aggregate $\mathrm{dFe}$ measurements according to water masses to better understand the role of physical transport, to assess the covariance (if any) between $\mathrm{dFe}$ and salinity anomalies that might reflect sea ice processes, explore the relation between Fe solubility (Liu and Millero, 2002) in such cold waters and measured $\mathrm{dFe}$ or to use macronutrient data to calculate drawdown ratios. In the near future the 'intermediate data product' of the GEOTRACES programme should provide the per- fect vehicle to undertake this analysis with a compendium of GEOTRACES era dFe data alongside appropriate metadata. Nevertheless, we do highlight the importance of adequate seasonal coverage when conducting such an analysis, since, for example, the lack of data at the seasonal dFe maxima or during ice melt/formation period can hinder the quantification of seasonal drawdown calculations or appraising the role of sea ice as a $\mathrm{dFe}$ source/sink, respectively.

Our understanding of the interactions between $\mathrm{dFe}$ and biological activity hinged on the a priori assumption that biological consumption was the primary means by which $\mathrm{dFe}$ was impacted. One would then imagine an inverse relationship between $\mathrm{dFe}$ concentrations and indices of biological production (usually from satellite data). While the differences in $\mathrm{dFe}$ between the Subantarctic and Antarctic regions do reflect the inter-region trends in productivity when the dynamics between $\mathrm{dFe}$ and biology are examined in more detail on seasonal timescales, a more complicated pattern emerges. Despite the seasonal $\mathrm{dFe}$ minima being associated with the end of the growing season at SR3, dFe was found to increase in phase with Chl- $a$ during the early season (Fig. 4a and $b$ ). This implies either that seasonal dFe patterns in spring-summer are dominated by external inputs (mediated by physical mixing) or that the signal of biology is dominated by recycling terms. For example, a number of attempts 
to construct $\mathrm{dFe}$ budgets have highlighted the so-called "ferrous wheel" as the dominant Fe flux term (e.g., Strzepek et al., 2005; Frew et al., 2006; Bowie et al., 2009; Boyd and Ellwood, 2010). The "ferrous wheel" encompasses Fe recycling processes associated with zooplankton grazing, higher trophic levels, bacterial turnover, as well as dissolution of particle Fe (e.g., Strzepek et al., 2005; Frew et al., 2006; Tovar-Sanchez et al., 2007; Nicol et al., 2010). While we might imagine greater herbivory and associated $\mathrm{Fe}$ recycling to be associated with higher Chl- $a$ levels, which would then be in accord with the associated high values of $\mathrm{dFe}$, we lack quantitative data. More field measurements of the ferrous wheel terms (e.g., zooplankton and bacterial production rates) associated with $\mathrm{dFe}$ observations (perhaps part of bioGEOTRACES efforts) are therefore necessary to better understand their potentially significant impact on seasonal iron cycle dynamics across the wider Southern Ocean and to permit a robust interpretation of the measured dFe trends.

\section{Conclusions}

We have compiled $13125 \mathrm{dFe}$ observations covering the global ocean and encompassing the period 1978-2008 and make this available to the community for future studies (please contact one of the corresponding authors). Moreover, we have conducted a more detailed synthesis and analysis of the 3332 observations taken in the Southern Ocean, where Fe plays a fundamental role in regulating primary productivity and the carbon cycle. This analysis was performed within 4 different ocean regions and 6 different ocean basins across 5 depth intervals and highlights inter-basin and inter-region variability in the profiles of $\mathrm{dFe}$ and their variability. At the surface, differences in $\mathrm{Fe}$ inputs (both exogenous and vertical) or biological activity might explain the variability we find between the Subantarctic and Antarctic regions or the ATL and IND sector, while at depth we suggest a role for heterogeneity in Fe-binding ligands and deep Fe sources such as hydrothermal vents. The profile of $\mathrm{dFe}$ might be linked to upwelling of UCDW south of the polar front. In surface waters, dFe data collected in recent years (2003-2008) are significantly different from data collected previously, while deeper values show little statistical differences. We also note the substantial progress made in Southern Ocean dFe sampling in recent years (more than half of all Southern Ocean observations are from the past $5 \mathrm{yr}$ ) as part of the GEOTRACES programme. However, despite these efforts the seasonal cycle of $\mathrm{dFe}$ and its relationship to biological productivity/cycling remains enigmatic, even in some of the most well- sampled regions of the Southern Ocean. In fact, we find that neither the SR3 seasonal nor inter-basin trends (between the ATL, IND and PAC) in $\mathrm{dFe}$ are driven by biological consumption, which suggests that, apart from broad Antarctic Subantarctic trends, other processes might be the dominant driver of $\mathrm{dFe}$ variability (e.g., dFe recycling exogenous in- puts, or mixed layer dynamics). However, there are no dFe measurements available for the Southern Ocean from May, June, August and September, and we highlight in particular the nature of the autumn-winter-spring transition in $\mathrm{dFe}$ as a key gap in our knowledge. We hope that identifying these issues can help in the planning of future voyages to the region.

Acknowledgements. We thank all scientists who collected and contributed $\mathrm{dFe}$ data for this effort, as well as K. Johnson, P. Parekh and J. K. Moore for beginning the compilation of dFe datasets. A. T. especially thanks Peter Sedwick who kindly passed on measurements and a preprint ahead of their publication, as well as commenting on the seasonality of SR3, and Hein de Baar for useful comments on our approach. The authors thank Nicolas Fauchereau for providing the plot on the seasonal chlorophyll progression for the SR3 region. Finally we extend our thanks to Peter Croot and Stéphane Blain for their critical reviews of our manuscript and for highlighting the importance and utility of associated metadata that we comment upon in the text. A. T., T. M. and S. S. acknowledge support from ACCESS. A copy of the dataset is available from GEOTRACES (http://www.bodc.ac.uk/geotraces/data/historical/) or by emailing either of the corresponding authors. We will endeavour to continue to compile newly available measurements and encourage scientists to contribute to this effort by contacting A. T.

Edited by: G. Herndl

\section{References}

Achterberg, E. P., Holland, T. W., Bowie, A. R., Mantoura, R. F. C., and Worsfold, P. J.: Determination of iron in seawater, Anal. Chim. Acta, 442, 1-14, 2001.

Archer, D. E., and Johnson, K.: A model of the iron cycle in the ocean, Global Biogeochem. Cy., 14, 269-279, 2000.

Arrigo, K. R. and van Dijken, G. L.: Impact of iceberg C-19 on Ross Sea primary production, Geophys. Res. Lett., 30, 1836, doi:10.1029/2003GL017721, 2003.

Arrigo, K. R., van Dijken, G. L., and Bushinsky, S.: Primary production in the Southern Ocean, 1997-2006, J. Geophys. Res. COceans, 113, 8, 2008.

Arrigo, K. R. and Van Dijken, G. L.: Annual changes in sea-ice, chlorophyll a, and primary production in the Ross Sea, Antarctica, Deep Sea Res. Pt. II, 51, 117-138, 2004.

Arrigo, K. R., van Dijken, G. L., Ainley, D. G., Fahnestock, M. A., and Markus, T.: Ecological impact of a large Antarctic Iceberg, Geophys. Res. Lett., 29, 1104, doi:2001GL014160, 2002.

Blain, S., Queguiner, B., Armand, L., Belviso, S., Bombled, B., Bopp, L., Bowie, A., Brunet, C., Brussaard, C., Carlotti, F., Christaki, U., Corbiere, A., Durand, I., Ebersbach, F., Fuda, J. L., Garcia, N., Gerringa, L., Griffiths, B., Guigue, C., Guillerm, C., Jacquet, S., Jeandel, C., Laan, P., Lefevre, D., Lo Monaco, C., Malits, A., Mosseri, J., Obernosterer, I., Park, Y. H., Picheral, M., Pondaven, P., Remenyi, T., Sandroni, V., Sarthou, G., Savoye, N., Scouarnec, L., Souhaut, M., Thuiller, D., Timmermans, K., Trull, T., Uitz, J., Van Beek, P., Veldhuis, M., Vincent, D., Viollier, E., Vong, L., and Wagener, T.: Effect of natural iron 
fertilization on carbon sequestration in the Southern Ocean, Nature, 446, 7139, 1070-1074, 2007.

Bowie, A. R. and Lohan, M. C.: Determination of iron in seawater, in: Practical Guidelines for the Analysis of Seawater, Chapt. 12, edited by: Wurl, O., Taylor and Francis, Boca Raton, 235-257, 2009.

Bowie, A. R., Sedwick, P. N., and Worsfold, P. J.: Analytical intercomparison between flow injection-chemiluminascence and flow injection-spectrophotometry for the determination of picomolar concentrations of iron in seawater, Luminol. Oceanogr. Meth., 2, 42-54, 2004.

Bowie, A. R., Archtenberg, E. P., Croot, P. L., de Baar, H. J. W., Laan, P., Sarthou, G., and Worsfold, P. J.: A community-wide intercomparison exercise for the determination of dissolved iron in seawater, Mar. Chem., 98, 81-99, 2006.

Bowie, A. R., Lannuzel, D., Remenyi, T. A., Wagener, T., Lam, P. J., Boyd, P. W., Guieu, C., Townsend, A. T., and Trull, T. W.: Biogeochemical iron budgets of the Southern Ocean south of Australia: Decoupling of iron and nutrient cycles in the subantarctic zone by the summertime supply, Global Biogeochem. Cy., 23, GB4034, 14 pp., doi:10.1029/2009GB003500, 2009.

Boyd, P. W. and Ellwood, M. J.: The biogeochemical cycle of iron in the ocean, Nat. Geosci., 3, 675-682, 2010.

Boyd, P. W., Law, C. S., Wong, C. S., Nojiri, Y., Tsuda, A., Levasseur, M., Takeda, S., Rivkin, R., Harrison, P. J., Strzepek, R., Gover, J., McKay, R. M., Abraham, E., Arychuk, M., BarwellClark, J., Crawford, W., Crawford, D., Hale, M., Harada, K., Johnson, K., Kiyosawa, H., Kudo, I., Marchetti, A., Miller, W., Needoba, J., Nishioka, J., Ogawa, H., Page, J., Robert, M., Saito, H., Sastri, A., Sherry, N., Soutar, T., Sutherland, N., Taira, Y., Whitney, F., Wong, S. E., and Yoshimura, T.: The decline and fate of an iron-induced subarctic phytoplankton bloom, Nature, 428, 549-553, 2004.

Boyd, P. W., Jickells, T., Law, C. S., Blain, S., Boyle, E. A., Buesseler, K. O., Coale, K. H., Cullen, J. J., de Baar, J. W., Follows, M., Harvey, M., Lancelot, C., Levasseur, M., Owens, N. P. J., Pollard, R., Rivkin, R. B., Sarmiento, J., Schoemann, V., Smetacek, V., Takeda, S., Tsuda, A., Turner, S., and Watson, A. J.: Mesoscale iron enrichment experiments 1993-2005: synthesis and future directions, Science, 315, 612-617, 2007.

Boye, M., Nishioka, J., Croot, P., Laan, P., Timmermans, K. R., Strass, V. H., Takeda, S., and de Baar, H. J. W.: Significant portion of dissolved organic Fe complexes in fact is colloids, Mar. Chem., 122, 20-27, 2010.

Bruland, K. W. and Rue, E. L.: Iron: analytical methods for the determination of concentrations and speciation, in: The Biogeochemistry of Iron in Seawater, edited by: Hunt, K. A. and Turner, D. R., John Wiley, Hoboken, 255-289, 2001.

Bruland, K. W., Franks, R. P., Knauer, G. A., and Martin, J. H.: Sampling and analytical method for determination of copper, cadmium, zinc, and nickel at the nanogram per litre level in seawater, Anal. Chim. Acta, 105, 233-245, 1979.

Caldeira, K. and Duffy, P. B.: The role of the Southern Ocean in uptake and storage of anthropogenic carbon dioxide, Science, 287, 620-622, 2000.

Chever, F., Bucciarelli, E., Sarthou, G., Speich, S., Arhan, M., Penven, P., and Tagliabue, A.: Physical speciation of iron in the Atlantic sector of the Southern Ocean along a transect from the subtropical domain to the Weddell Gyre, J. Geophys. Res., 115,
C10059, doi:10.1029/2009JC005880, 2010.

Coale, K. H., Gordon, R. M., and Wang, X.: The distribution and behaviour of dissolved and particulate iron and zinc in the Ross Sea and Antarctic Circumpolar current along $170^{\circ} \mathrm{W}$, Deep-Sea Res. Pt. I, 52, 295-318, 2005.

Croot, P. L., Andersson, K.,Öztürk, M., and Turner, D. R.: The distribution and speciation of iron along $6^{\circ} \mathrm{E}$ in the Southern Ocean, Deep-Sea Res. Pt. II, 51, 2857-2879, 2004.

Croot, P. L.: Interactive comment on "A global compilation of over 13000 dissolved iron measurements: focus on distributions and processes in the Southern Ocean" by A. Tagliabue et al., Biogeosciences Discuss., 8, C6271-C6271, 2012.

de Baar H. J. W., Boyd, P. W., Coale, K. H., Landry, M. R., Tsuda, A., Assmy, P., Bakker, D. C. E., Bozec, Y., Barber, R. T., Brzezinski, M. A., Buesseler, K. O., Boyé, M., Croot, P. L., Gervais, F., Gorbunov, M. Y., Harrison, P. J., Hiscock, W. T., Laan, P., Lancelot, C., Law, C. S., Levasseur, M., Marchetti, A., Millero, F. J., Nishioka, J., Nojiri, Y., van Oijen, T., Riebesell, U., Rijkenberg, M. J. A., Saito, H., Takeda, S., Timmermans, K. R., Veldhuis, M. J. W., Waite, A. M., and Wong, C.-S.: Synthesis of iron fertilization experiments: from the iron age in the age of enlightenment, J. Geophy. Res. Oceans, 110, C09S16, 2005.

de Baar, H. J. W., de Jong, J. M. T., Baker, D. C. E., Loscher, B. M., Veth, C., Bathmann, U., and Smatacek, V.: Importance of iron for plankton blooms and carbon dioxide draw down in the Southern Ocean, Nature, 373, 412-415, 1995.

de Baar, H. J. W., de Jong, J. T. M., Notling, R. F., Timmermans, K. R., van Leeuwe, M. A., Bathman, U., van der Loeff, M. R., and Sildam, J.: Low dissolved Fe and the absence of diatom blooms in remote Pacific waters of the Southern Ocean, Mar. Chem., 66, 1-34, 1999.

de Boyer-Montégut, C., G. Madec, A. S. Fischer, A. Lazar, and D. Iudicone, Mixed layer depth over the global ocean: an examination of profile data and a profile-based climatology, J. Geophys. Res., 109, C12003, doi:10.1029/2004JC002378, 2004.

Ellwood, M. J., Boyd, P. W., and Sutton, P.: Winter-time dissolved iron and nutrient distributions in the Subantarctic Zone from $40-52^{\circ} \mathrm{S} ; 155-160^{\circ} \mathrm{E}$, Geophys. Res. Lett., 35, L11604, doi:10.1029/2008GL033699, 2008.

Fitzwater, S. E., Johnson, K. S., Gordon, R. M., Coale, K. H., and Smith Jr., W. O.: Trace metal concentrations in the Ross Sea and their relationship with nutrients and growth, Deep-Sea Res. Pt. II, 47, 3159-3178, 2000.

Frew, R. D., Hutchins, D. A., Nodder, S., Sanudo-Wilhelmy, S., Tovar-Sanchez, A., Leblanc, K., Hare, C. E., and Boyd, P. W.: Particulate iron dynamics during FeCycle in subantarctic waters southeast of New Zealand, Global Biogeochem. Cy., 20, GB1S93, doi:10.1029/2005GB002558, 2006.

Gaiero, D. M., Probst, J. L., Depetris, P. J., Bidart, S. M., and Leleyter, L.: Iron and other transition metals in Patagonian riverborne and windborne materials: geochemical control and transport to the Southern South Atlantic Ocean, Geochim. Cosmochim. Ac., 67, 3603-3623, doi:10.1016/S00167037(03)00211-4, 2003.

Gordon, A. L.: Circulation of the Caribbean Sea, J. Geophys. Res., 72, 6207-6223, 1967.

Grotti, M., Abelmoschi, M. L., Soggia, F., Rivaro, P., Magi, E., and Frache, R.: Temporal distribution of trace metals in Antarctic coastal waters, Mar. Chem., 76, 189-209, 2001. 
Hoppema, M., de Baar, H. J. W., Fahrbach, E., Hellmer, H. H., and Klein, B.: Substantial advective iron loss diminishes phytoplankton production in the Antarctic Zone, Global Biogoechem. Cy., 17(1), 1025, doi:10.1029/2002GB001957, 2003.

Hudson, R. J. M., Rue, E. L., and Bruland, K. W.: Modeling Complexometric Titrations of NaturalWater Samples, Environ. Sci. Technol., 37, 1553-1562, 2003.

Ibisamni, E. B., Sander, S. G., Boyd, P. W., Bowie, A. R., and Hunter, K. A.: Vertical distributions of Iron(III) complexing ligands in the Southern Ocean, Deep-Sea Res. Pt. II, 58, 21132125, 2011.

Johnson, K. S., Gordon, R. M., and Coale, K. H.: What controls dissolved Iron concentration in the World Ocean? Mar. Chem., 57, 137-161, 1997.

Johnson, K., Boyle, E., Bruland, K., Coale, K., Measures, C., Moffett, J., Aguilar-Isla, A., Barbeau, K., Bergquist, B., Bowie, A., Buck, K., Cai, Y., Chase, Z., Cullen, J., Doi, Y., Elrod, V., Fitzwater, S., Gordon, M., King, A., Laan, P., Laglera-Baquer, L., Landing, W., Lohan, M., Mendez, J., Milne, A., Obata, H., Ossiander, L., Plant, J., Sarthou, G., Sedwick, P., Smith, G. J., Sohst, B., Tanner, S., van dend Berg, C. M. G., and Wu, J.: Developing standards for dissolved iron in seawater, EOS, 88, 131-132, 2007.

Klein, P. and Lapeyre, G.: The oceanic vertical pump induced by mesoscale eddies, Annu. Rev. Mar. Sci., 1, 351-375, 2009.

Klunder, M., Laan, P., Middag, R., de Baar, H. J. W., and Van Ooijen, J.: Dissolved iron in the Southern Ocean (Atlantic Sector), Deep-Sea Res. Pt. II, 58, 2678-2694, 2011.

Klunder, M., Laan, P., and de Baar, H. J. W.: Distribution of dissolved iron in the Weddell Sea and Drake Passage, in preparation, 2012.

Lai, X., Norisuye, K., Mikata, M., Minami, T., Bowie, A. R., and Sohrin, Y.: Spatial and temporal distribution of $\mathrm{Fe}, \mathrm{Ni}, \mathrm{Cu}$, and $\mathrm{Pb}$ along $140^{\circ} \mathrm{E}$ in the Southern Ocean during austral summer 2001/2002, Mar. Chem., 111, 171-183, 2008.

Lannuzel, D., Schoemann, V., de Jong, J., Chou, L., Delille, B., Becquevort, J. L., and Tison, S.: Iron study during a time series in the Western Weddell pack ice, Mar. Chem., 108, 85-95, 2008.

Lannuzel, D., Schoemann, V., de Jong, J., Pasquer, B., van der Merwe, P., Masson, F., Tison, J.-L., and Bowie, A.: Distribution of dissolved iron in Antarctic sea ice: Spatial, seasonal, and inter-annual variability, J. Geophys. Res., 115, G03022, 13 pp., doi:10.1029/2009JG001031, 2010.

Lévy, M., Klein, P., and Treguier, A. M.: Impacts of sub-mesoscale physics on phytoplankton production and subduction, J. Mar. Res., 59, 535-565, doi:10.1357/002224001762842181, 2001.

Liu, X., and Millero, F. J.: The solubility of iron in seawater, Mar. Chem., 77, 43-54, 2002.

Löscher, B. M., de Baar, H. J. W., de Jong, J., Veth, C., and Dehairs, F.: The distribution of Fe in the Antartic circumpolar current, Deep-Sea Res. Pt. II, 44, 143-187, 1997.

Maamaatuaiahutapu, K., Garcon, V., Provost, C., and Mercier, H.: Transports of the Brazil and Malvinas currents at their confluence, J. Mar. Res., 56, 417-438, 1998.

Martin, J. H.: Glacial-interglacial $\mathrm{CO}_{2}$ change: the iron hypothesis, Paleoceanography, 5, 1-13, 1990.

Martin, J. H., Gordon, R. M., and Fitzwaters, S. E.: Iron in Antarctic waters, Nature, 345, 156-158, 1990.

Measures, C. I. and Vink, S.: Dissolved iron in the upper waters of the Pacific sector of the Southern Ocean, Deep-Sea Res. Pt. II,
48, 3913-3941, 2001.

Measures, C. I., Landing, W. M., Brown, M. T., and Buck, C. S.: A commercially available rosette system for trace metal-clean sampling, Limnol. Oceanogr. Meth., 6, 384-394, 2008.

Moore, J. K. and Braucher, O.: Sedimentary and mineral dust sources of dissolved iron to the world ocean, Biogeosciences, 5, 631-656, doi:10.5194/bg-5-631-2008, 2008.

Nicol, S., Bowie, A., Jarman, S., Lannuzel, D., Meiners, K. M., and van der Merwe, P.: Southern Ocean iron fertilization by baleen whales and Antarctic krill, Fish Fisheries Serie, doi:10.1111/j.1467-2979.2010.00356.x, 2010.

Parekh, P., Follows, M. J., and Boyle, E. A.: Decoupling of Iron and Phosphate in the Global Ocean, Global Biogeochem. Cy., 19, GB2020, doi:10.1029/2004GB002280, 2005.

Peterson, R. G. and Stramma, L.: Upper-level circulation in the South Atlantic Ocean, Prog. Oceanogr., 26, 1-73, 1990.

Pollard, R. T., Salter, I., Sanders, R. J., Lucas, M. I., Moore, C. M., Mills, R. A., Statham, P. J., Allen, J. T., Baker, A. R., Bakker, D. C. E., Charette, M. A., Fielding, S., Fones, G. R., French, M., Hickman, A. E., Holland, R. J., Hughes, J. A., Jickells, T. D., Lampitt, R. S., Morris, P. J., Nédélec, F. H., Nielsd`ttir, M., Planquette, H., Popova, E. E., Poulton, A. J., Read, J. F., Seeyave, S., Smith, T., Stinchcombe, M., Taylor, S., Thomalla, S., Venables, H. J., Williamson, R., and Zubkov, M. V.: Southern Ocean deep-water carbon export enhanced by natural iron fertilization, Nature, 157, 577-580. doi:10.1038/nature07716, 2009.

Rio, M.-H. and Hernandez, F.: A mean dynamic topography computed over the world ocean from altimetry, in situ measurements, and a geoid model, J. Geophys. Res., 109, C12032, 19, doi:10.1029/2003JC002226, 2004.

Sedwick, P. N., Edwards, P. R., Mackey, D. J., Griffiths, F. B., and Parslow, J. S.: Iron and manganese in surface waters of the Australian subantarctic region, Deep-Sea Res. Pt. I, 44, 1239-1253, 1997.

Sedwick, P. N., DiTullio, G. R., Hutchins, D. A., Boyd, P. W., Griffiths, F. B., Crossley, A. C., Trull, T. W., and Queguiner, B.: Limitation of algal growth by iron deficiency in the Australian Subantarctic region, Geophys. Res. Lett., 26, 2865-2868, 1999.

Sedwick, P. N., DiTullio, G. R., and Mackey, D. J.: Iron and manganese in the Ross Sea, Antarctic: seasonal iron limitation in Antarctic shelf waters, J. Geophys. Res., 105, 11321-11336, 2000.

Sedwick, P. N., Bowie, A. R., and Trull, T. W.: Dissolved iron in the Australian sector of the Southern Ocean (CLIVAR SR3 section): meridional and seasonal trends, Deep-Sea Res. Pt. I, 55, 911925, 2008.

Sedwick, P. N., Marsay, C. M., Aguilar-Islas, A. M., Lohan, M. C., Sohst, B. M., Long, M. C., Arrigo, K. R., Bruland, K. W., DiTullio, G. R., Dunbar, R. B., Saito, M. A., and Smith, W. O.: Early-season iron depletion in the Ross Sea polynya: Implications for iron dynamics on the Antarctic continental shelf, J. Geophys. Res., 116, C12019, doi:10.1029/2010JC006553, 2011.

Sohrin, Y., Iwamoto, S., Matsui, M., Obata, H., Nakayama, E., Suzuki, K., Handa, N., and Ishii, M.: The distribution of Fe in the Australian sector of the Southern Ocean, Deep-Sea Res. Pt. 1, 47, 55-84, 2000.

Sokolov, S. and Rintoul, S. R.: On the relationship between fronts of the Antarctic Circumpolar Current and surface chlorophyll concentrations in the Southern Ocean, J. Geophy. Res., 112, C07030, 
doi:10.1029/2006JC004072, 2007.

Strzepek, R. F., Maldonado, M. T., Higgins, J. L., Hall, J., Safi, K., Wilhelm, S. W., and Boyd, P. W.: Spinning the "Ferrous Wheel": The importance of the microbial community in an iron budget during the FeCycle experiment, Global Biogeochem. Cy., 19, GB4S26, doi:10.1029/2005/gb002490, 2005.

Swart, S. and Speich, S.: An altimetry-based gravest empirical mode south of Africa: 2. Dynamic nature of the ACC fronts, J. Geophys. Res., 115, C03003, 1-21, doi:10.1029/2009JC005300, 2010.

Tagliabue, A. and Arrigo, K.: Processes governing the supply of iron to phytoplankton in stratified seas, J. Geophy. Res., 111, C06019, doi:10.1029/2005JC003363, 2006.

Tagliabue, A., Bopp, L., and Aumont, O.: Evaluating the importance of atmospheric and sedimentary iron sources to Southern Ocean biogeochemistry, Geophys. Res. Lett., 36, L13601, doi:10.1029/2009GL038914, 2009.

Tagliabue, A., Bopp, L., Dutay, J.-C., Bowie, A. R., Chever, F., Jean-Baptiste, P., Bucciarelli, E., Lannuzel, D., Remenyi, T., Sarthou, G., Aumont, O., Gehlen, M., and Jeandel, C.: Hydrothermal contribution to the oceanic dissolved iron inventory, Nat. Geosci., 3, 252-256, 2010.
Tovar-Sanchez, A., Duarte, C. M., Hernández-León, S., and Sañudo-Wilhelmy, S. A.: Krill as a central node for iron cycling in the Southern Ocean, Geophys. Res. Lett., 34, L11601, 4 pp., doi:10.1029/2006GL029096, 2007.

Thuroczy, C.-E., Gerringa, L. J. A., Klunder, M. B., Laan, P., and de Baar, H. J. W.: Observation of consistent trends in the organic complexation of dissolved iron in the Atlantic Sector of the Southern Ocean, Dee-Sea Res. Pt. 2, 58, 2695-2706, 2011.

Trull, T. W., Schulz, E., Bray, S. G., Pender, L., McLaughlan, D., Tilbrook, B., Rosenberg, M., and Lynch, T.: The Australian Integrated Marine Observing System Southern Ocean Time Series facility, OCEANS 2010 IEEE, Sydney, doi:10.1109/OCEANSSYD.2010.5603514, 2010.

van der Merwe, P., Lannuzel, D., Bowie, A. R., Mancuso Nichols, C. A., and Meiners, K. M.: Iron fractionation in pack and fast ice in East Antarctica: Temporal decoupling between the release of dissolved and particulate iron during spring melt, Deep-Sea Res. Pt. II, 58, 1222-1236, 2011.

Wu, J., Boyle, E., Sunda, W., and Wen, L.-S.: Soluble and colloidal iron in the oligotrophic North Atlantic and North Pacific, Science, 293, 847-849, 2001. 